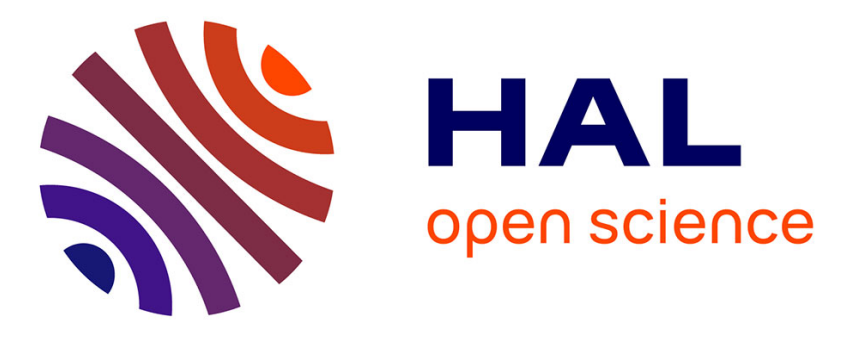

\title{
Spatially distributed modelling of surface water-groundwater exchanges during overbank flood events - a case study at the Garonne River
}

Léonard Bernard-Jannin, David Brito, Xiaoling Sun, Eduardo Jauch, Ramiro Neves, Sabine Sauvage, Jose-Miguel Sanchez-Perez

\section{To cite this version:}

Léonard Bernard-Jannin, David Brito, Xiaoling Sun, Eduardo Jauch, Ramiro Neves, et al.. Spatially distributed modelling of surface water-groundwater exchanges during overbank flood events a case study at the Garonne River. Advances in Water Resources, 2016, vol. 94, pp. 146-159. 10.1016/j.advwatres.2016.05.008 . hal-01348632

\section{HAL Id: hal-01348632 \\ https://hal.science/hal-01348632}

Submitted on 25 Jul 2016

HAL is a multi-disciplinary open access archive for the deposit and dissemination of scientific research documents, whether they are published or not. The documents may come from teaching and research institutions in France or abroad, or from public or private research centers.
L'archive ouverte pluridisciplinaire HAL, est destinée au dépôt et à la diffusion de documents scientifiques de niveau recherche, publiés ou non, émanant des établissements d'enseignement et de recherche français ou étrangers, des laboratoires publics ou privés. 


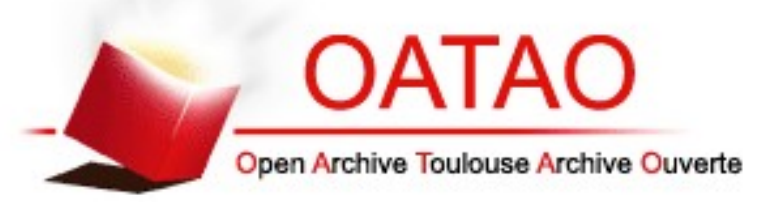

\section{Open Archive TOULOUSE Archive Ouverte (OATAO)}

OATAO is an open access repository that collects the work of Toulouse researchers and makes it freely available over the web where possible.

This is an author-deposited version published in : http://oatao.univ-toulouse.fr/ Eprints ID : 15892

To link to this article : DOI : 10.1016/j.advwatres.2016.05.008 URL : http://dx.doi.org/10.1016/j.advwatres.2016.05.008

To cite this version : Bernard-Jannin, Léonard and Brito, David and Sun, Xiaoling and Jauch, Eduardo and Neves, Ramiro and Sauvage, Sabine and Sanchez-Pérez, José-Miguel Spatially distributed modelling of surface water-groundwater exchanges during overbank flood events - a case study at the Garonne River. (2016) Advances in Water Resources, vol. 94. pp. 146-159. ISSN 0309-1708

Any correspondence concerning this service should be sent to the repository administrator: staff-oatao@listes-diff.inp-toulouse.fr 


\title{
Spatially distributed modelling of surface water-groundwater exchanges during overbank flood events - a case study at the Garonne River
}

\author{
Léonard Bernard-Jannin a,*, David Brito ${ }^{\mathrm{b}}$, Xiaoling Sun ${ }^{\mathrm{a}}$, Eduardo Jauch ${ }^{\mathrm{b}}$, Ramiro Neves ${ }^{\mathrm{b}}$, \\ Sabine Sauvage ${ }^{a}$, José-Miguel Sánchez-Pérez ${ }^{\mathrm{a}, *}$
}

a ECOLAB, Université de Toulouse, CNRS, INPT, UPS, Toulouse, France

${ }^{\mathrm{b}}$ MARETEC, Instituto Superior Técnico, Universidade de Lisboa, Av. Rovisco Pais, 1049-001 Lisboa, Portugal

Keywords:

Floodplain

Hydrological modelling

Water exchanges

River-aquifer interface

3D model

\begin{abstract}
A B S T R A C T
Exchanges between surface water (SW) and groundwater (GW) are of considerable importance to floodplain ecosystems and biogeochemical cycles. Flood events in particular are important for riparian water budget and element exchanges and processing. However SW-GW exchanges present complex spatial and temporal patterns and modelling can provide useful knowledge about the processes involved at the scale of the reach and its adjacent floodplain. This study used a physically-based, spatially-distributed modelling approach for studying SW-GW exchanges. The modelling in this study is based on the MOHID Land model, combining the modelling of surface water flow in 2D with the Saint-Venant equation and the modelling of unsaturated groundwater flow in 3D with the Richards' equation. Overbank flow during floods was also integrated, as well as water exchanges between the two domains across the entire floodplain. Conservative transport simulations were also performed to study and validate the simulation of the mixing between surface water and groundwater. The model was applied to the well-monitored study site of Monbéqui $\left(6.6 \mathrm{~km}^{2}\right)$ in the Garonne floodplain (south-west France) for a five-month period and was able to represent the hydrology of the study area. Infiltration (SW to GW) and exfiltration (SW to GW) were characterised over the five-month period. Results showed that infiltration and exfiltration exhibited strong spatiotemporal variations, and infiltration from overbank flow accounted for $88 \%$ of the total simulated infiltration, corresponding to large flood periods. The results confirmed that overbank flood events played a determinant role in floodplain water budget and SW-GW exchanges compared to smaller (below bankfull) flood events. The impact of floods on water budget appeared to be similar for flood events exceeding a threshold corresponding to the five-year return period event due to the study area's topography. Simulation of overbank flow during flood events was an important feature in the accurate assessment of exchanges between surface water and groundwater in floodplain areas, especially when considering large flood events.
\end{abstract}

\section{Introduction}

Exchanges at the interface between surface water (SW) and groundwater (GW) are known to play a key role in floodplain ecosystems (Amoros and Bornette, 2002, Sophocleous, 2002, Thoms, 2003). Areas of mixing between SW and GW are regions of intensified biogeochemical activity (Grimm and Fisher, 1984, McClain et al., 2003). These processes include denitrification,

* Corresponding author at: Avenue de l'Agrobiopole, 31326 Castanet Tolosan Cedex, France.

E-mail addresses: l.bernardjannin@gmail.com (L. Bernard-Jannin), josemiguel.sanchez-perez@univ-tlse3.fr (J.-M. Sánchez-Pérez). which has been recognised as the most important nitrate removal process in GW (Rivett et al., 2008) and can lead to significantly reduced nitrate concentrations in aquifers supporting agricultural activities (Sánchez-Pérez and Tremolières, 1997, Correll et al., 1992). Denitrification is known to be influenced by hydrological connectivity between SW and GW, and denitrification hotspots have been related to activation of the processes through the organic matter flux coming from surface water (Sánchez-Pérez et al., 2003, Bernard-Jannin et al., 2016). This natural mitigation process is reinforced by the dilution of contaminant concentrations due to the mixing between SW and GW (Pinay et al., 1998, Baillieux et al., 2014). In floodplains, flood events are an important feature for ecosystems. The pulsing of river discharge is the major driving 
force determining the exchange processes of organic matter and organisms across river-floodplain gradients (Junk et al., 1989, Tockner et al., 1999). Furthermore it is recognised that the overbank flow component has to be included in SW-GW exchanges for a comprehensive water balance assessment (Rassam et al., 2008). An accurate quantification and description of SW-GW exchanges, including overbank floods, is therefore a key factor when dealing with water quality in alluvial aquifers as it can help assess the patterns of activation of natural mitigation biogeochemical processes and dilution effects. However SW-GW interactions often present complex spatial and temporal patterns (Sophocleous, 2002, Krause et al., 2007) and a study at the scale of the stream and its adjacent floodplain (Woessner, 2000) is required to understand them fully.

As they allow characteristics of the environment to be taken into consideration on a detailed scale, physically-based, spatiallydistributed models are valuable tools for improving knowledge of SW-GW exchanges and assessing the three-dimensional nature of the problem (Sophocleous, 1998, Bradford and Acreman, 2003). Numerous studies featuring distributed models and including SWGW exchanges in floodplain areas have been carried out, encompassing SW-GW exchange patterns and biogeochemical zonation induced by meander sinuosity (Boano et al., 2006, Boano et al., 2010), heat transport (Brookfield et al., 2009, Horritt et al., 2006), 3D-flow patterns in relation to river level variations (Derx et al., 2010, Nützmann et al., 2013), hydrofacies heterogeneity impact on SW-GW exchanges (Frei et al., 2009), SW-GW exchange impact on floodplain water balance (Krause et al., 2007, Krause and Bronstert, 2007, Weng et al., 2003), solute transport through riparian areas (Weng et al., 2003, Hoffmann et al., 2006, Peyrard et al., 2008) and contribution of GW to stream water (Partington et al., 2011). While all these modelling studies integrate a surface and subsurface component as well as SW-GW exchanges, overbank flood events have not been included in the analysis. This can present a problem for assessing SW-GW exchanges in the floodplain accurately, especially during large flood events where infiltration from surface runoff can occur across the floodplain (Bates et al., 2000) and inundated areas can drive aquifer recharge patterns (Helton et al., 2014). Although overbank flood infiltration is not considered important when the river and aquifer are disconnected (Morin et al., 2009), it is recognised that the lack of an overbank flow component in models leads to an underestimation of infiltration of river water into the aquifer (Doppler et al., 2007, Engeler et al., 2011). In another study, overbank flow during flooding has been simulated to study floodplain contamination, but only vertical infiltration has been taken into account to evaluate pollutant deposition and subsurface flows have not been simulated (Stewart et al., 1998). In this case it is the simulation of subsurface flow returning to the river that is lacking in order to provide a comprehensive representation of SW-GW exchanges.

Overbank flood events are known to be very important for element processing and water budget in floodplain areas, but to the authors' knowledge they are not usually included in SW- GW studies. The main objective of this study was to assess the importance of overbank flood events on SW-GW interactions in a floodplain area. Using a distributed model, two domains - SW and GW were simulated and coupled through infiltration/exfiltration processes. These processes were simulated across the entire floodplain area in order to include the impact of overbank flood events on SW-GW exchange dynamic. The model was applied to a wellmonitored study site, providing a strong dataset for model validation, where SW-GW exchanges were analysed. A transport model was also included and the model was then used to evaluate SWGW exchanges spatially and temporally for different flood conditions in the study area. This study is also a prerequisite for future work involving the simulation of biogeochemical processes such as denitrification in floodplain areas.

\section{Materials and methods}

\subsection{Modelling approach}

The modelling strategy for a complete surface-subsurface flow system should include surface and subsurface components and the coupling between them (Furman, 2008). Numerous models belong to this category that differ in terms of the formulation of the component governing equations (including dimensionality) and their coupling strategy and technical solution (Maxwell et al., 2014). For subsurface flow, most of the models solve the Richards' equation (one, two or three dimensions) and solve a formulation of the Saint-Venant equation (kinematic, diffusive or dynamic wave in one or two dimensions) for the surface component (Furman, 2008). The models differ in terms of their coupling strategy involving asynchronous linking (Condon and Maxwell, 2013), sequential iteration (Dagès et al., 2012) or a globally implicit scheme (Kollet and Maxwell, 2006), and the technical solution involving boundary conditions (BC) switching (Dagès et al., 2012), first-order exchange (Panday and Huyakorn, 2004) or pressure continuity (Maxwell et al., 2014, Kollet and Maxwell, 2006). In a study comparing seven models with the different characteristics described above, it was found that the models demonstrate the same qualitative agreement although they use different approaches (Maxwell et al., 2014).

Out of the open-source models able to simulate SW-GW exchanges, MOHID Land was applied in this study. This model includes all features required to simulate impact of flood events on SW-GW exchanges. Subsurface flow was computed with the threedimensional Richard's equation needed to represent spatial variability of the flow in the unsaturated media of the floodplain area in detail. Surface flow was computed with the two-dimensional dynamic wave formulation of the Saint-Venant equation, allowing the correct representation of the rapidly changing stream stages during flooding. The coupling between the two components was produced through asynchronous linking and first-order exchange and realised across the entire modelled domain (i.e. not limited to the riverbed location). In addition, the model included a transport module. While these features are shared by several models, the novelty of the approach is to apply this type of model to simulate floodplain hydrology.

\subsubsection{Overview of the MOHID model}

MOHID Land is a part of the MOHID Water Modelling System (Neves et al., 2013) (www.mohid.com). It is a physically-based, spatially-distributed model designed to simulate the water cycle in hydrographic basins, including SW-GW interactions. It uses an object-oriented approach to facilitate the integration of different processes and modules, and a finite volume approach with a fluxdriven strategy to facilitate the coupling of processes and verify the conservation of mass and momentum (Trancoso et al., 2009, Braunschweig et al., 2004, Brito et al., 2015).

Although it was originally designed to model river network systems and watersheds (Trancoso et al., 2009), the modularity of MOHID Land allows the model to meet the specific features of a floodplain area. The model set-up used in this study consisted of two domains: the surface water (SW) domain and the porous media (PM) domain (Fig. 1). The hydrology of the SW domain was calculated according to the two-dimensional Saint-Venant equation (dynamic wave). The river geometry was included in the SW domain to ensure the continuity of surface runoff simulation over the floodplain during overbank flood events. Water fluxes in the PM domain were calculated in three dimensions for saturated and unsaturated media using the Buckingham-Darcy equation. The spatially-distributed structure allowed interactions between the two domains - infiltration from SW to PM and exfiltration from 


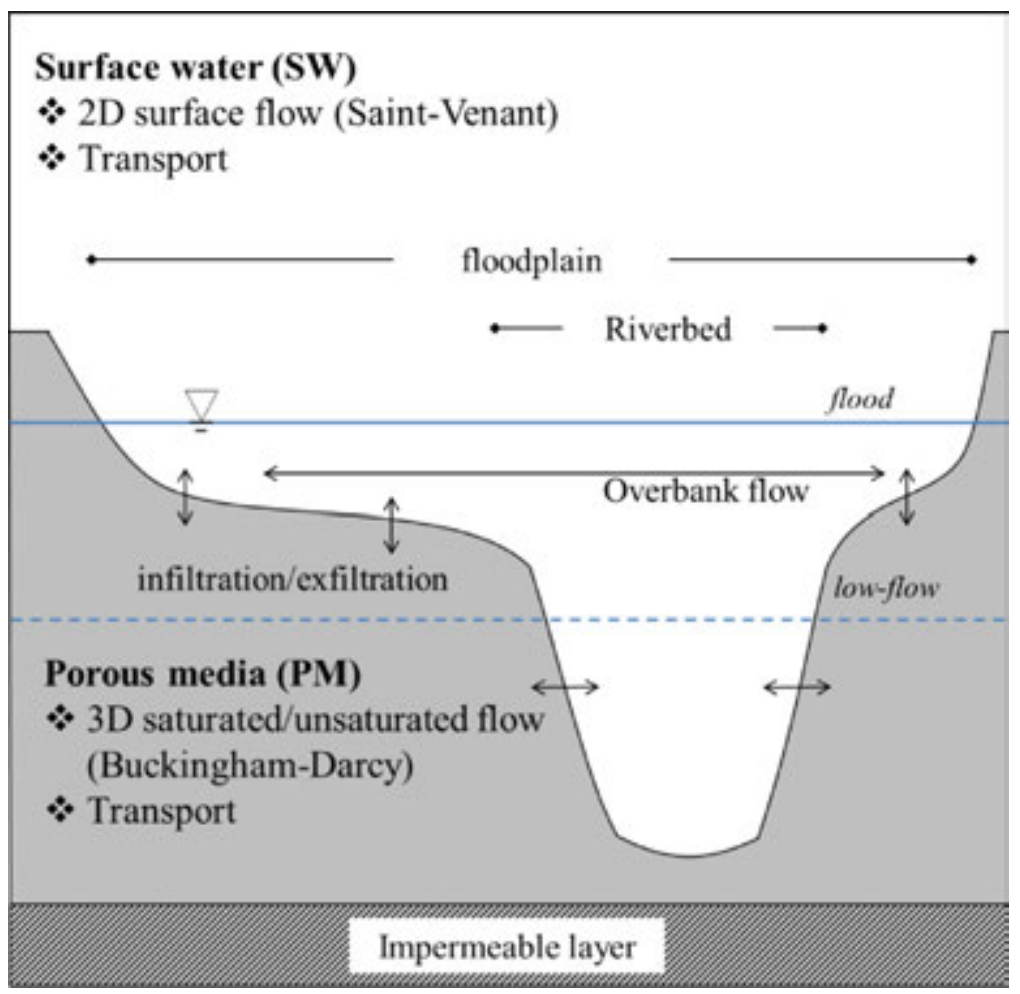

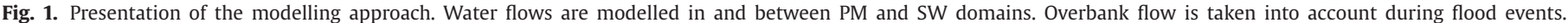
Transport is considered in both domains.

PM to SW - to occur across the floodplain area at each time step. The possibility of imposing boundary conditions for the simulated domain in SW and PM was implemented in the model for the purposes of this study. Transport of chloride $\left(\mathrm{Cl}^{-}\right)$as a conservative element was also simulated. Input data construction and output data visualisation were facilitated using the graphical user interface MOHID Studio. Due to its object-oriented modelling strategy, MOHID Land can provide a basis for further modelling studies in alluvial plains by facilitating the incorporation of modules designed to simulate biogeochemical processes for example.

\subsubsection{Governing equations of MOHID Land}

MOHID Land is a grid-based model with an Arkawa C-grid type (Purser and Leslie, 1988) in which flows and velocities are computed at the cell interfaces, while properties such as water content are computed at the centre of each cell. Unsaturated and saturated flows are computed in three dimensions in the PM domain, and surface flow in two dimensions (horizontal) in the SW domain where horizontal PM and SW grids are matching. Processes in each domain are calculated using a finite volume method to guarantee mass conservation, and solved with an explicit scheme. The model first computes PM processes, including infiltration/exfiltration, followed by SW processes.

Porous media flow. First, water velocity is computed in each cell interface of the saturated and unsaturated medium using the Buckingham-Darcy equation (Swartzendruber, 1969) (1):

$v_{i}=-K(\theta)\left(\frac{\partial H}{\partial x_{i}}\right)$

where $v_{i}\left[\mathrm{~m} \mathrm{~s}^{-1}\right]$ is the water velocity at the cell interface along direction $i, x_{i}[\mathrm{~m}]$ is the distance along direction $i, K\left[\mathrm{~m} \mathrm{~s}^{-1}\right]$ is hydraulic conductivity and $\theta[-]$ is the cell water content. $H[\mathrm{~m}]$ is the hydraulic head computed in each cell centre as shown in Eq. 2:
$H=h+\psi+z$

where $h[m]$ is the suction head, $\psi[m]$ is the static pressure head and $z[m]$ is the elevation of the centre of the cell.

The governing equation for flow in the porous media result from the combination of the Buckingham-Darcy Eq. (1) and the continuity equation and is known as Richards' equation (Brito et al., 2015, Richards, 1931) (3).

$\frac{\partial \theta}{\partial t}=\frac{\partial}{\partial x_{i}}\left[K(\theta) \frac{\partial H}{\partial x_{i}}\right]$.

The model uses the combination of the Mualem model (Mualem, 1976), which calculates the hydraulic conductivity in unsaturated soils (4 and 5), and the van Genuchten model (van Genuchten, 1980) for computing water retention in soils (6):

$K(\theta)=K_{S} \cdot S_{E}{ }^{L} \cdot\left(1-\left(1-S_{E}{ }^{1 /\left(1-\frac{1}{N}\right)}\right)^{1-1 / N}\right)^{2}$

$S_{E}=\left(\theta-\theta_{r}\right) /\left(\theta_{s}-\theta_{r}\right)$

$h(\theta)=-S_{E}^{(-1 /(1-1 / N))}-1^{1 / N \mid} / \alpha$

where $\theta_{r}[-]$ is the residual water content, $\theta_{s}[-]$ is the saturated water content, $\alpha\left[\mathrm{cm}^{-1}\right]$ is a term related to the inverse of the air entry pressure, $N$ (dimensionless) is a measure of the pore-size distribution, $S_{E}[-]$ is the effective saturation, $L$ is an empirical poreconnectivity parameter and $K_{S}\left[\mathrm{~m} \mathrm{~s}^{-1}\right]$ is the saturated hydraulic conductivity.

PM fluxes are calculated in the three-space direction, and vertical infiltration between SW and GW is then computed by applying the Darcy equation between SW and the top PM layer (Fig. 2, 


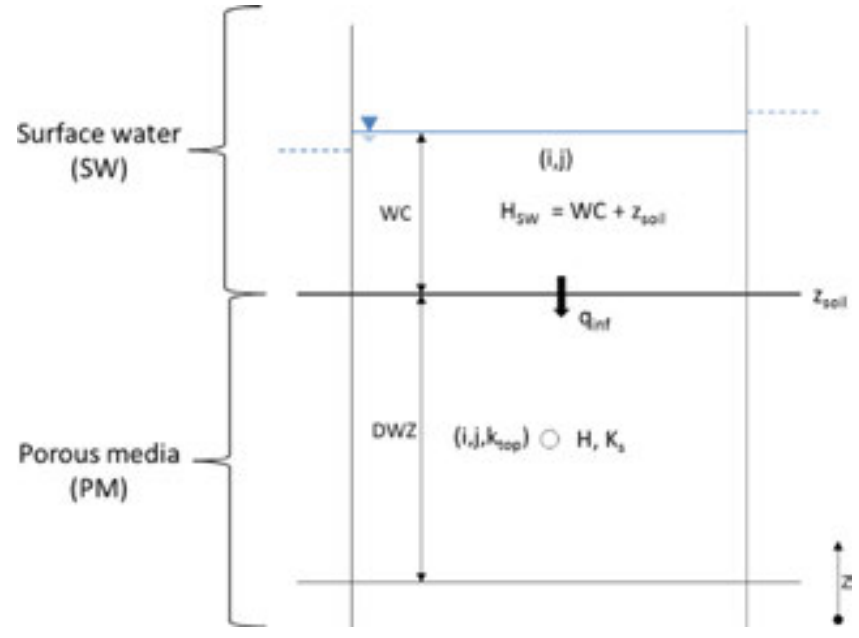

Fig. 2. Schematic of the vertical infiltration flux $\left(q_{\text {inf }}\right)$ calculation between SW cells $(\mathrm{i}, \mathrm{j})$ and the top PM cells $\left(\mathrm{i}, \mathrm{j}, \mathrm{k}_{\mathrm{top}}\right)$. WC is the surface water column in SW and $\mathrm{z}_{\text {soil }}$ is the elevation of the soil surface. DWZ is the thickness, $\mathrm{H}$ is the hydraulic head and $\mathrm{K}_{\mathrm{s}}$ is the saturated hydraulic conductivity of the top PM cell. $\mathrm{i}$ and $\mathrm{j}$ are the horizontal cell coordinates, $\mathrm{k}_{\text {top }}$ represents the vertical coordinate of the upper layer.

Eq. 7):

$q_{\text {inf }}(i, j)=K_{s}\left(i, j, k_{\text {top }}\right) A(i, j)\left[\frac{H_{S W}(i, j)-H\left(i, j, k_{\text {top }}\right)}{W C(i, j)+0.5 D W Z\left(i, j, k_{\text {top }}\right)}\right]$

where $q_{\text {inf }}$ is the vertical infiltration flux $\left[\mathrm{m}^{3} \mathrm{~s}^{-1}\right], A$ is the area of the cell $\left[\mathrm{m}^{2}\right], H_{S W}$ is the surface water elevation [m], WC is the surface water column [m], DWZ is the PM cell vertical height, $i, j$ are the cell horizontal coordinates and $k_{\text {top }}$ is the top PM layer coordinate.

To avoid negative volume in SW, the infiltration flux $\mathrm{q}_{\text {inf }}$ is limited to the available water volume in SW domain. Then $\theta^{t+d t}$ is updated in each cell of the PM domain according to the continuity (Eq. (8)):

$\theta^{t+d t}=\left[\theta^{t} V+\left(q_{x}+q_{y}+q_{z}+q_{\text {inf }}\right) d t / V\right.$

where $\theta^{t+d t}$ is the updated cell water content at time step $\mathrm{t}+\mathrm{dt}[-]$, $\theta^{t}$ is the cell water content at time step $\mathrm{t}[-], V$ is the cell volume $\left[\mathrm{m}^{3}\right], d t$ is the time step [s], and $q_{x}, q_{y}, q_{z}$ are the fluxes along the three space directions $\mathrm{x}, \mathrm{y}$ and $\mathrm{z}\left[\mathrm{m}^{3} \mathrm{~s}^{-1}\right]$.

Finally, for each cell the water content $\theta^{t+d t}$ is compared to the saturated water content $\theta_{s}$. If $\theta^{t+d t}>\theta_{S}$ the excess of the cell water volume $\left(\theta^{t+d t}-\theta_{S}\right)$ is transferred first to the underlying cells if space is available and then to the upper cells. When all the cells of the column are saturated, the eventual remaining excess water volume is reallocated to the SW domain (exfiltration). This means that mass conservation is satisfied and $\theta^{t+d t} \leq \theta_{S}$ in every cell of the PM domain.

Surface water flow. Surface water flow is then computed, solving the 2D Saint-Venant equation (dynamic wave) in its conservative form, accounting for advection, pressure and friction forces (Chow et al., 1988) for the two horizontal directions of the grid (9 and 10):

$$
\begin{aligned}
& \frac{\partial Q_{x}}{\partial t}+v_{x} \frac{\partial Q_{x}}{\partial x}+v_{y} \frac{\partial Q_{x}}{\partial y}=-g \cdot A\left(\frac{\partial H}{\partial x}+\frac{|Q| \cdot Q_{x} \cdot n^{2}}{A^{2} \cdot R_{h}^{4 / 3}}\right) \\
& \frac{\partial Q_{y}}{\partial t}+v_{x} \frac{\partial Q_{y}}{\partial x}+v_{y} \frac{\partial Q_{y}}{\partial y}=-g \cdot A\left(\frac{\partial H}{\partial y}+\frac{\mid Q^{\prime / 3} \cdot Q_{y} \cdot n^{2}}{A^{2} \cdot R_{h}^{4 / 3}}\right)
\end{aligned}
$$
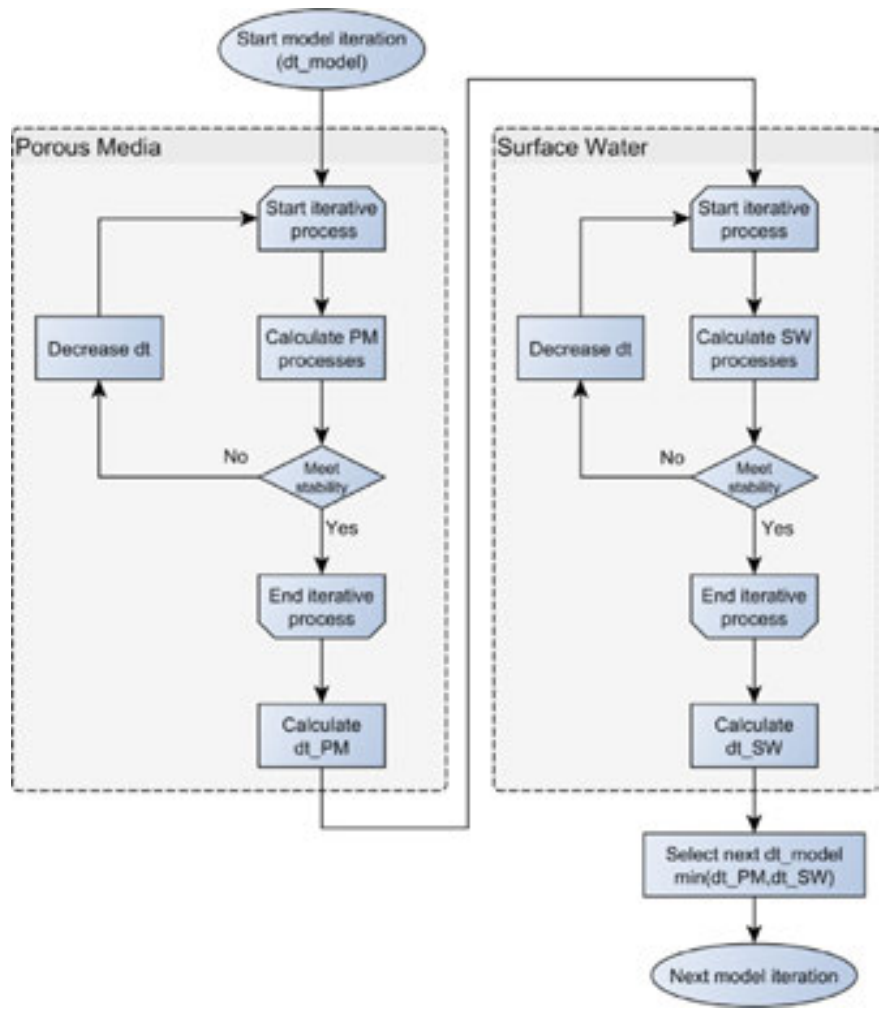

Fig. 3. Schematic of time step management (see text for explanations).

where $Q\left[\mathrm{~m}^{3} \mathrm{~s}^{-1}\right]$ is the flow at a cell face along the two horizontal directions of the grids $x$ and $y, v\left[\mathrm{~m} \mathrm{~s}^{-1}\right]$ is the flow velocity along the $x$ and $y$ directions, $g\left[\mathrm{~m} \mathrm{~s}^{-2}\right]$ is the gravitational acceleration, $A\left[\mathrm{~m}^{2}\right]$ is the cross-section of the water column, $H$ is the water column $[\mathrm{m}], n\left[\mathrm{~s} \mathrm{~m}^{-1 / 3}\right]$ is the Manning coefficient, $R_{h}[\mathrm{~m}]$ is the hydraulic radius, and $x$ and $y[\mathrm{~m}]$ are the distances along the two horizontal directions of the grid. The water volume and water column in each cell are then updated according to the continuity equation.

Transport. Transport of properties is computed in SW and PM through the advection-diffusion Eqs. (11 and 10):

$\frac{\partial \beta}{\partial t}=-\frac{\partial(\beta . v)}{\partial x_{i}}+\frac{\partial \gamma \vec{\nabla} \beta}{\partial x_{i}}$

$\gamma=\alpha_{i} \cdot v_{i}$

where $\beta$ is the property concentration in $\left[\mathrm{g} \mathrm{m}^{-3}\right], x_{i}[\mathrm{~m}]$ is the distance along the direction $i, \gamma$ is the diffusivity $\left[\mathrm{m}^{2} \mathrm{~s}^{-1}\right]$ and $\alpha_{i}$ is the dispersivity along the direction $i[\mathrm{~m}]$.

\subsubsection{Time step control and stability}

MOHID Land uses an adaptive time step (Fig. 3). Starting from an initial time step defined for the whole model ( $\left.\mathrm{dt}_{\text {model }}\right)$, an iterative process is performed within each domain (PM and SW) for which a stability criterion is defined. In PM, it corresponds to the maximum water volume variation allowed in a cell. In SW the time step is controlled by limiting the Courant number. In each domain the time step is reduced and the number of iterations increased until the criterion is met. The fluxes are then integrated for each domain over $\mathrm{dt}_{\text {model }}$. At the end of the iterative process, a time step is calculated for each domain $\left(\mathrm{dt}_{\mathrm{PM}}\right.$ and $\left.\mathrm{dt}_{\mathrm{SW}}\right)$. This time step corresponds to an increased value of the $\mathrm{dt}_{\text {model }}$ if one iteration is enough to meet the stability criterion or a decreased value of 

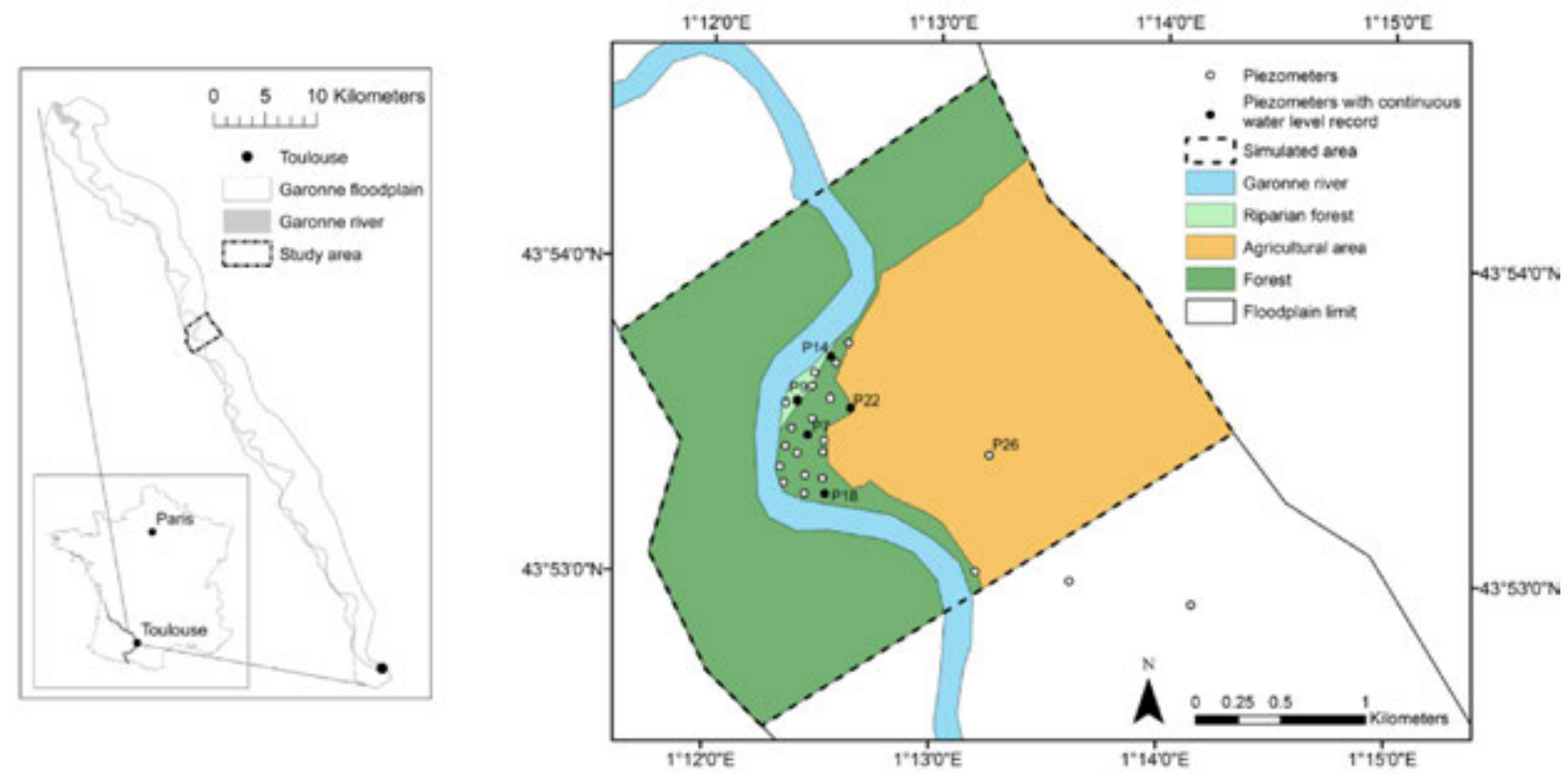

Fig. 4. Study site location, simulated area and piezometer location.

the $\mathrm{dt}_{\text {model }}$ if more than one iteration is needed to compute domain processes. The $\mathrm{dt}_{\text {model }}$ is then updated, corresponding to the minimum between $\mathrm{dt}_{\mathrm{SW}}$ and $\mathrm{dt}_{\mathrm{PM}}$ and the next model iteration is computed. This procedure avoids negative volumes and optimises simulation time cost without compromising model stability. This is particularly important in explicit methods and to avoid numerical dispersion (Trancoso et al., 2009).

\subsection{Study site}

The Garonne River is a 525 km-long river flowing from the Pyrenees in Spain to the Atlantic Ocean in the Gironde estuary in France. The flow regime is influenced by both the rainy season in the Massif Central and snow melting in the Pyrenean mountains. The middle section of the Garonne River is considered to be the $70 \mathrm{~km}$ long floodplain between the confluence with the Ariege River and the confluence with the Tarn River, north of the city of Toulouse. This area is characterised by a two to four kilometrewide floodplain and a $150 \mathrm{~m}$-wide river with a slope less than $0.1 \%$ (Steiger et al., 1998). The study reach is a $3.4 \mathrm{~km}-l$ long meandershaped channel in the middle section of the Garonne and its floodplain located near the village of Monbéqui, about $30 \mathrm{~km}$ downstream of Toulouse, covering an area of about $6.6 \mathrm{~km}^{2}$ (Fig. 4). The land cover is composed of a riparian forest close to the river $\left(0.5 \mathrm{~km}^{2}\right)$, an agricultural area located on the right side of the river $\left(3.5 \mathrm{~km}^{2}\right)$ and a poplar plantation $\left(2.3 \mathrm{~km}^{2}\right)$ located between the riparian forest and the agricultural area on the left side of the river. Hourly discharge is recorded at the Verdun-sur-Garonne gauging station (www.hydro.eaufrance.fr) located $3.5 \mathrm{~km}$ upstream, with no major tributary between the station and the studied reach. At this location, the drainage area is about $13,730 \mathrm{~km}^{2}$. Annual average flow is about $190 \mathrm{~m}^{3} \mathrm{~s}^{-1}$, ranging from $98 \mathrm{~m}^{3} \mathrm{~s}^{-1}$ in 1989 to $315 \mathrm{~m}^{3} \mathrm{~s}^{-1}$ in 1978 , over the past 41 years. The driest month is August with $76 \mathrm{~m}^{3} \mathrm{~s}^{-1}$ on average and the wettest is May with $343 \mathrm{~m}^{3} \mathrm{~s}^{-1}$ on average. The daily flow is highly variable, ranging from $10 \mathrm{~m}^{3} \mathrm{~s}^{-1}$ during the severe drought in August 1991 to $2930 \mathrm{~m}^{3} \mathrm{~s}^{-1}$ for the largest flood event recorded on 6 November 2000. The floodplain is filled with between four to seven metres of quaternary sand and gravel deposits overlying the impermeable molassic bedrock (Lancaster, 2005). In this area the Garonne River fully penetrates the alluvial formation, implying that the riverbed lies on the impermeable substratum (Weng et al., 2003). Several studies have been conducted on this study site, including 3D groundwater modelling (Weng et al., 2003), 2D SW-GW interaction modelling (Peyrard et al., 2008), modelling of nitrate leaching under agricultural fields (Jégo et al., 2012), and the relationship between the bacteria community structure and denitrification hotspots (Iribar et al., 2008).

A network of 24 piezometers was installed in the inner part of the study meander (Fig. 4). The available data consist of the hydraulic head measured at a monthly time step in each piezometer and 15 min water levels in five piezometers (P7, P9, P14, P18, P22) recorded by pressure sensor (CTD-Diver, Schlumberger) from April 2013 to March 2014.

In addition, monthly campaigns were conducted from April 2013 to March 2014, during which groundwater samples were taken in every piezometer and $\mathrm{Cl}^{-}$concentrations, among other parameters, analysed. To ensure that the water sample corresponded to the aquifer and not to stagnant water accumulated in the piezometer, groundwater was extracted beforehand until insitu measured electrical conductivity was constant (Sánchez-Pérez, 1992).

\subsection{Model implementation}

\subsubsection{Model geometry}

The model geometry implemented for the study area involved a horizontal 2D grid with a $25 \mathrm{~m}$ cell side length for a total simulated area of $6.6 \mathrm{~km}^{2}$. The PM domain has to be defined between the surface topography and a bottom layer. As the riverbed lies on impermeable molassic bedrock, the bottom layer was considered to be impermeable and located $20 \mathrm{~cm}$ under the riverbed. The geometry of the impermeable bottom layer followed the slope of the riverbed. The vertical layers were built from the surface to the bottom layer, with a fixed depth for each layer. The number of layers was adjusted in each cell to match as closely as possible the elevation difference between the surface and the bottom layers according to the vertical discretisation consisting of a maximum of 


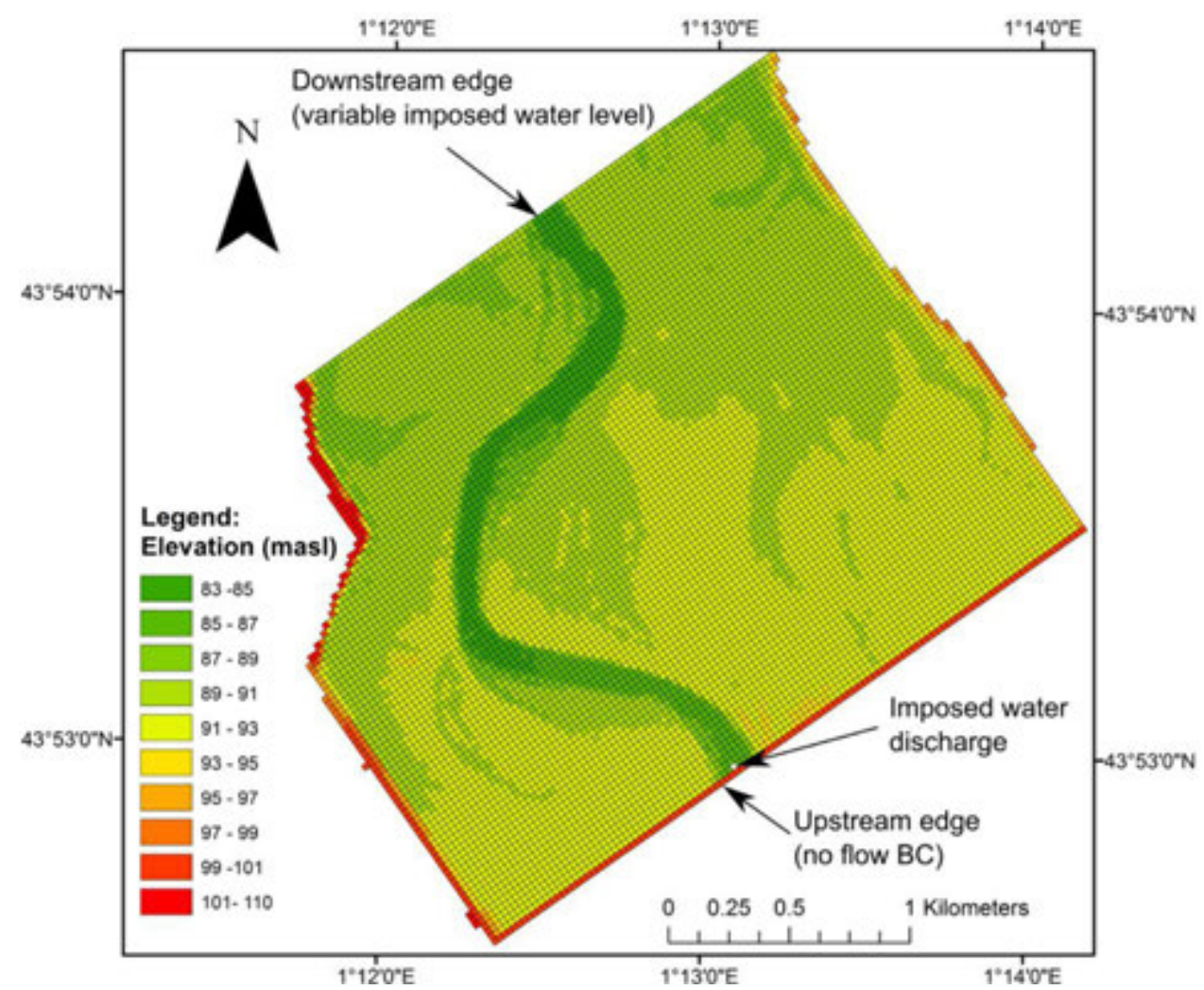

Fig. 5. Digital terrain model (DTM) according to model grid resolution $(25 \mathrm{~m})$ and SW domain boundary conditions.

Table 1

Model parameters.

\begin{tabular}{lllll}
\hline Domain & Symbol & Unit & Signification & Value \\
\hline Porous media (PM) & $\theta_{\mathrm{s}}$ & - & Saturated water content & 0.41 \\
& $\theta_{\mathrm{r}}$ & - & Residual water content & 0.06 \\
$\mathrm{~N}$ & - & Pore size distribution related term & 1.62 \\
& $\mathrm{~A}$ & $\mathrm{~cm}^{-1}$ & Air entry pressure related term & 0.56 \\
& $\mathrm{Ks}$ & $\mathrm{m} \mathrm{s}^{-1}$ & Saturated hydraulic conductivity & $10^{-3}$ \\
& $\alpha_{\mathrm{H}}$ & $\mathrm{m}$ & Horizontal dispersivity & 15 \\
& $\alpha_{\mathrm{V}}$ & $\mathrm{m}$ & Vertical dispersivity & 1.5 \\
Surface water $(\mathbf{S W})$ & $\mathrm{n}_{\mathrm{r}}$ & $\mathrm{s} \mathrm{m}^{-1 / 3}$ & Manning riverbed & 0.01 \\
& $\mathrm{n}_{\mathrm{f}}$ & $\mathrm{s} \mathrm{m}^{-1 / 3}$ & Manning floodplain & 0.1 \\
\hline
\end{tabular}

ten layers $0.2,0.3,0.5,1,1,1,1,1,1$ and 1 metre thick respectively from top to bottom.

The digital terrain model (DTM) required by the model was created by averaging the $1 \mathrm{~m}$ resolution LiDAR DTM (IGN) in the $25 \mathrm{~m}$ grid. According to the modelling strategy, the river geometry needs to be defined in the DTM. As the original DTM did not provide the elevation of the riverbed, the river was manually dug according to available river profiles along the river (Sauvage, 1999). The $25 \mathrm{~m}$ resolution permitted a good representation of the riverbed geometry, with a minimum of three cells to represent the riverbed width (Fig. 5).

\subsubsection{Model parameterisation}

Model parameterisation was undertaken a priori based on available data and knowledge to assess the ability of applying the model without a time-consuming calibration stage. The model parameters were Van Genuchten parameters (5) for the PM domain and the Manning coefficient for the SW domain (Table 1). Soil parameters used by the Van Genuchten model were obtained from pedotransfer functions (PTF) based on soil texture values, corresponding to a neural network developed and included in the
ROSETTA software (Schaap et al., 2001). N, $\alpha, \theta_{\mathrm{s}}$ and $\theta_{\mathrm{r}}$ were derived from this PTF using a soil texture composed of $28 \%$ sand, $52 \%$ loam and $20 \%$ clay, corresponding to measured field data (Jégo et al., 2012). The saturated hydraulic conductivity Ks was set to $10^{-3} \mathrm{~m} \mathrm{~s}^{-1}$, corresponding to the average of the measurements on the study site (Peyrard et al., 2008) and matching the coarse texture of the floodplain aquifer. The Manning coefficients were different for the riverbed and the floodplain, and were extracted from (Chow, 1959) and reduced to 0.01 and $0.1 \mathrm{~s} \mathrm{~m}^{-1 / 3}$ respectively for the riverbed $\left(\mathrm{n}_{\mathrm{r}}\right)$ and the floodplain $\left(\mathrm{n}_{\mathrm{f}}\right)$ since the Manning coefficient should be lower for 2D models (Néelz, 2009). Horizontal dispersivity $\alpha_{\mathrm{H}}$ was set at $15 \mathrm{~m}$ in accordance with a previous simulation (Peyrard et al., 2008) and vertical dispersivity $\alpha_{\mathrm{V}}$ was set ten times lower at $1.5 \mathrm{~m}$.

\subsubsection{Initial and boundary conditions of the model}

Initial conditions included hydraulic heads in PM obtained through the interpolation of the observations in the piezometers. In the unsaturated zone, water content was set to be equal to field capacity. Initial $\mathrm{Cl}^{-}$concentrations in PM were also required. However, due to the lack of observation points in the agricultural area, 


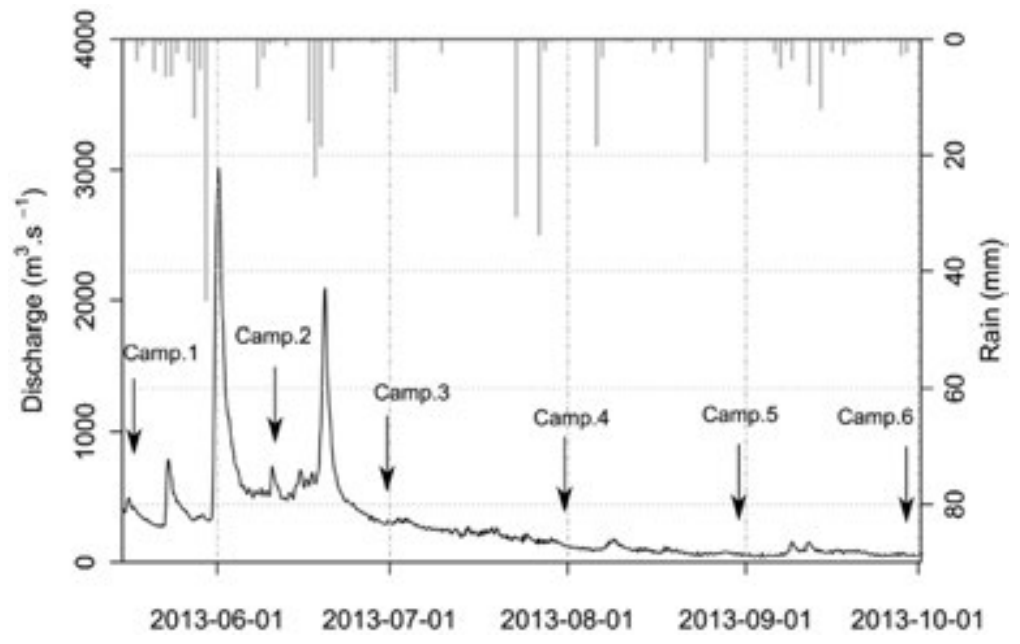

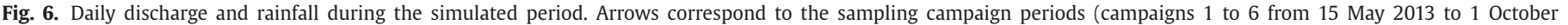
2013).

knowledge of the spatial variability of $\mathrm{Cl}^{-}$concentrations in this area is limited. Therefore two scenarios with different initial $\mathrm{Cl}^{-}$ concentrations for the agricultural area were tested and called IC80 and IC150, with a constant concentration in the agricultural area of $80 \mathrm{mg} \mathrm{L}^{-1}$ and $150 \mathrm{mg} \mathrm{L}^{-1}$ respectively, corresponding to the range of observed concentrations. For the rest of the area, the IC corresponded to the interpolation of observed concentrations for both scenarios. The initial water level in SW was defined according to a preliminary simulation run, with constant discharge corresponding to the first discharge value of the simulation period.

The boundary condition for PM was set to no flow conditions. This assumption was based on a previous simulation study which shows that lateral exchanges between the river and the groundwater are more important than groundwater recharge through the domain boundary (Peyrard et al., 2008). This behaviour was confirmed by the low longitudinal hydraulic head gradient of 0.001 measured in the study area. The boundary condition for $\mathrm{Cl}^{-}$concentrations was null gradient. The water level for the SW boundary condition on the downstream edge was imposed according to the river level recorded at the Verdun-sur-Garonne gauging station and transposed to the downstream edge of the modelled domain. Due to the higher elevation on the lateral edges resulting from the alluvial valley topography, the runoff could not exit through the sides. In the upstream edge, the boundary condition for SW was no flow (Fig. 5). Furthermore in SW, the hourly water discharge recorded in the Verdun gauging station was imposed in the cell located in the middle of the river closest to the upstream boundary. The $\mathrm{Cl}^{-}$concentration of the imposed discharge was set at a constant of $9 \mathrm{mg}$ $\mathrm{L}^{-1}$, corresponding to the average of the measured concentrations in the river.

The simulation period was from 15 May to 1 October 2013, characterised by a first flood with a five to 10 -year return period, followed by a second smaller flood corresponding to a two to fiveyear return period, and a three-month drying stage period (Fig. 6).

\subsubsection{Model evaluation and analysis}

The evaluation of the quality of the simulations included the calculation of the Nash-Sutcliffe coefficient (NS) (Je and Sutcliffe, 1970), root mean square error (RMSE), percent bias between simulations and observations (PBIAS) (Sorooshian et al., 1993), and coefficient of determination $\left(\mathrm{R}^{2}\right)$. The hydraulic head was continuously recorded by pressure sensors in five piezometers (P7, P9, P14, P18, and P22) and monthly manual records were also taken for all the piezometers. Observed hydraulic heads were compared to the hydraulic head simulated in the deeper cell corresponding to each piezometer location. $\mathrm{Cl}^{-}$concentrations analysed monthly were compared to the average of the simulated $\mathrm{Cl}^{-}$concentrations over the saturated area. Daily infiltration and exfiltration were separated between the area corresponding to the riverbed (including the banks) and the rest of the simulated domain corresponding to the floodplain. Positive values corresponded to infiltration (SW to $\mathrm{PM}$ ) and negative value to exfiltration (PM to SW).

\subsubsection{Application to different return period flood events}

The model was applied to simulate water exchanges for two, five, 10 and 20-year return period floods according to the French Banque Hydro archives. The floods consist of a 16-day period equivalent to the linear transformation of the flow values observed during the flood recorded between 29 May 2013 and 7 June 2013, to match the instantaneous peak flow values corresponding to the return period $\left(1800,2700,3200\right.$ and $3700 \mathrm{~m}^{3} \mathrm{~s}^{-1}$ for the two, five, 10 and 20-year return periods respectively).

\section{Results}

\subsection{Hydraulic heads}

The simulated hydraulic head and the observed hydraulic head for the 24 piezometers over the five campaigns from June to October 2013 (campaigns 2 to 6, Fig. 6) are shown in Fig. 7. Overall, the model was able to reproduce the observation correctly, with RMSE of $0.33 \mathrm{~m}, \mathrm{R}^{2}$ of 0.92 and NS of 0.90 for the hydraulic head recorded monthly in all the piezometers. However there was a slight overestimation of the simulated hydraulic head (PBIAS $=0.2 \%$ ). This is especially true for P26, which is the furthest piezometer from the river (Fig. 4). Fig. 7 shows the temporal series of observed and simulated hydraulic heads for the five piezometers equipped with continuous water level-recording sensors. With regard to the scoring parameters, P9 and P18 hydraulic heads were the best simulated, with the highest NS $(0.85,0.88)$ and $R^{2}(0.89,0.91)$ and the lowest RMSE $(0.38$ and $0.33 \mathrm{~m})$ out of the five piezometers. However, differences were observed between the piezometers. P9 offered a good representation of the hydraulic head during the peak flow, while the hydraulic head in P18 was simulated more closely for the recession curve. P7 exhibited behaviour close to P9. Finally P22 and P14 were the least satisfactory ( NS $=0.71$ and 0.65 ). Hydraulic heads during the first peak flow (1 June 2013) were generally well represented in the model, while the values for the second 
P9
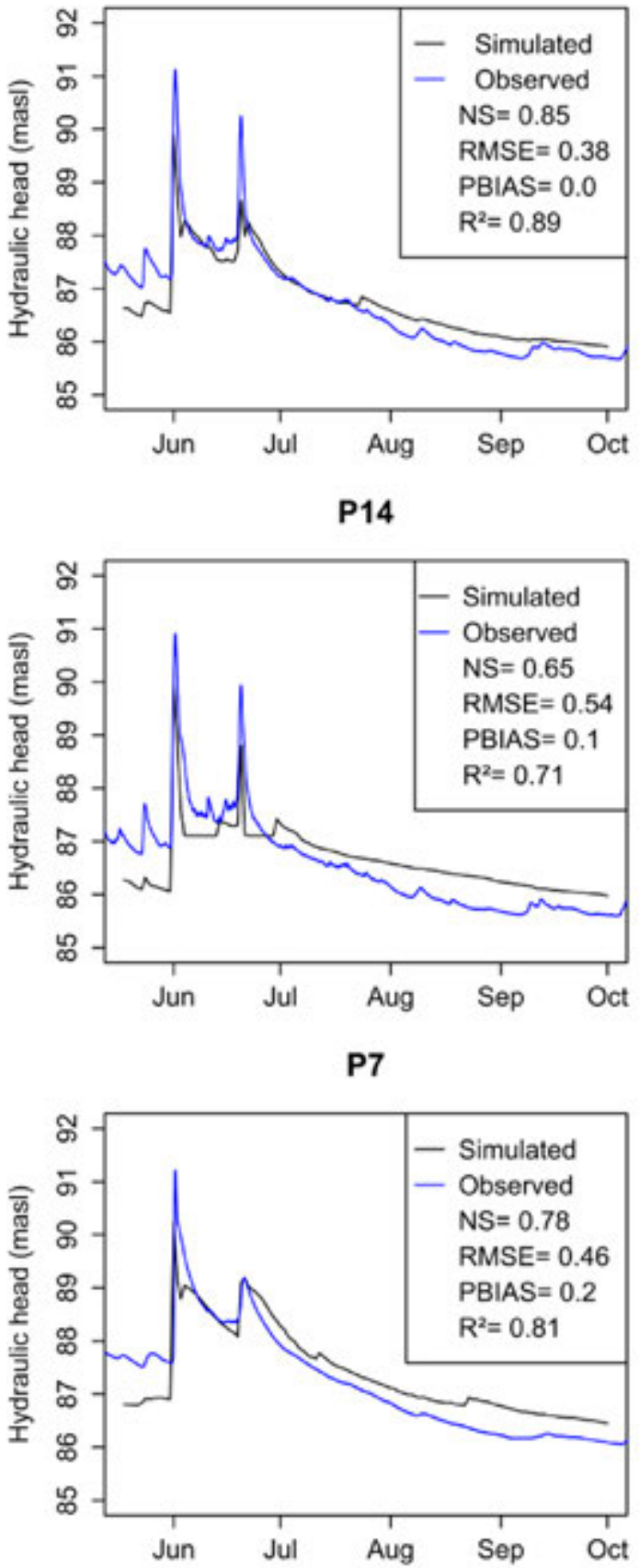

P22
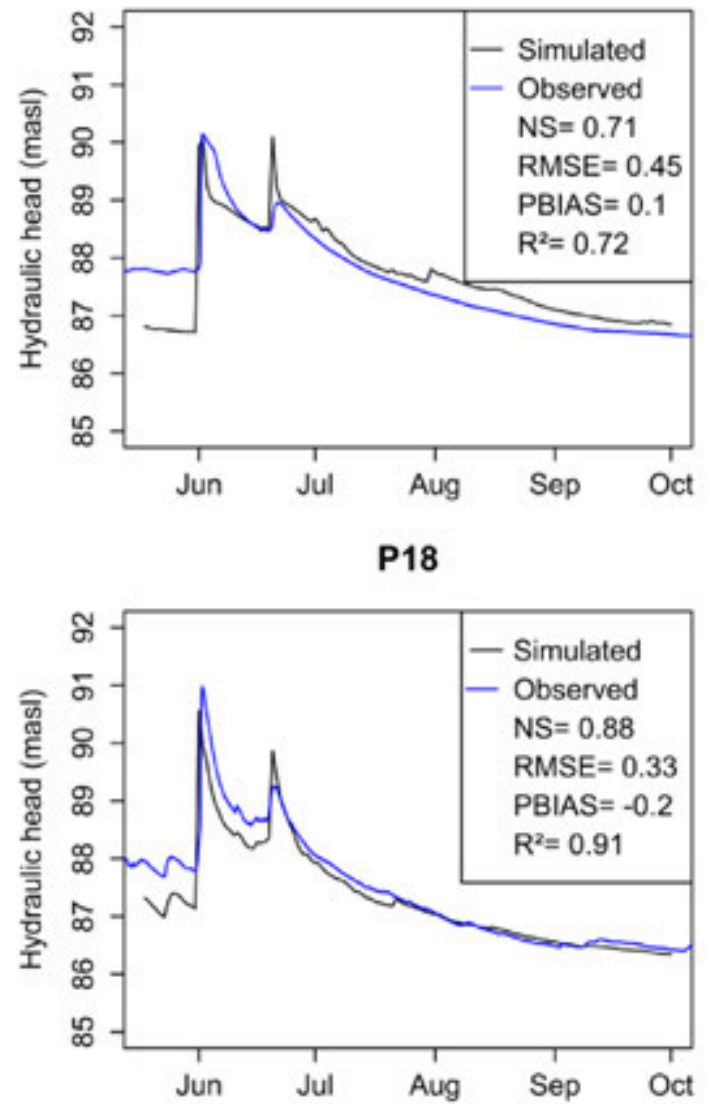

All piezometers

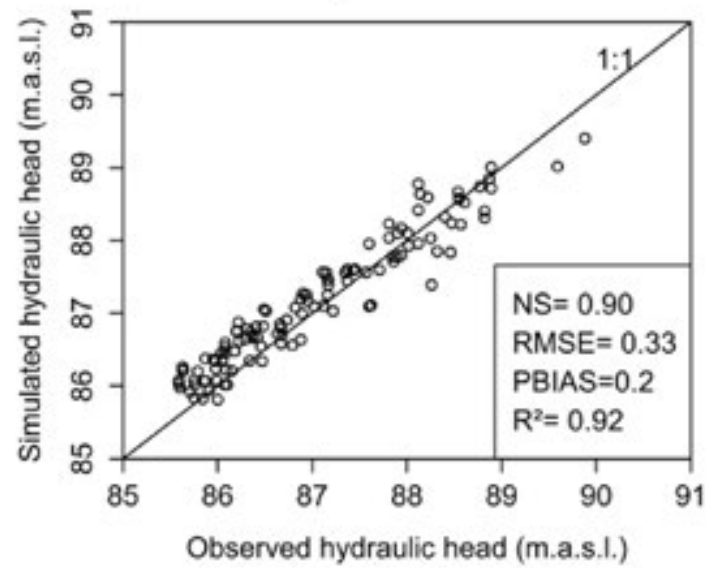

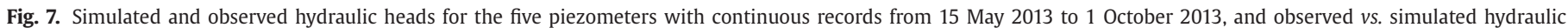
head in the 24 piezometers for sampling campaigns 1 to 5 .

peak flow (19 June 2013) were overestimated. On the whole, the hydraulic heads at the end of the recession period were slightly overestimated. Water level greater than soil surface was recorded by the continuous sensors in three of the five piezometers (P9, P14 and P7) during the peak flow of the flood on 1 June 2013 and can be interpreted as flood overbank flow. However, the simulation results indicated that overbank flow occurred at all the piezometer locations. The initial water table is underestimated for all the piezometers. This reflects the influence of the model vertical discretisation. In fact, during the initialisation stage, the model con- siders that the cell located directly below the measured water level is the top saturated cell of the soil profile, leading to a consistent underestimation of the initial water table level whose extent depends on the vertical discretisation.

\subsection{SW-GW exchanges}

Simulated daily exchanges between SW and PM across the entire simulated area are shown in Fig. 8, together with river discharge. The total infiltration water volume of $3.46 \times 10^{6} \mathrm{~m}^{3}$ 


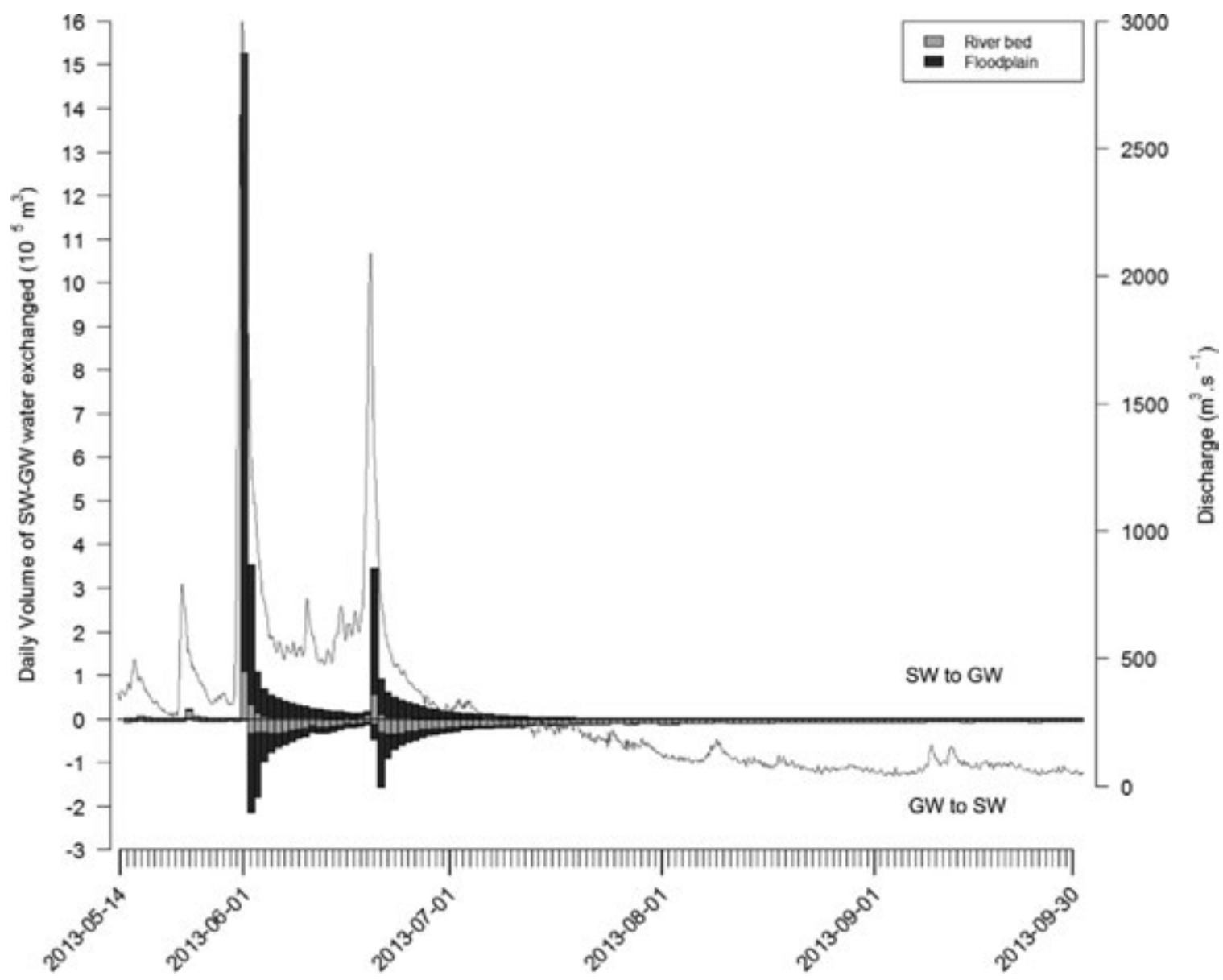

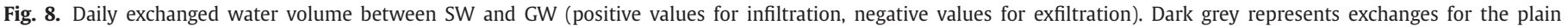
area, and light grey for the riverbed area. Hourly discharge is shown by a black solid line.

corresponded to an average of $425 \mathrm{~mm}$ over the $6.6 \mathrm{~km}^{2}$ simulated area and represented $49 \%$ of the maximum aquifer water volume attained on 1 June 2013. During the simulated period, the infiltrated volume was $0.43 \times 10^{6} \mathrm{~m}^{3}$ in the riverbed location and $3.04 \times 10^{6} \mathrm{~m}^{3}$ in the floodplain, while the exfiltrated volume was $1.68 \times 10^{6} \mathrm{~m}^{3}$ in the riverbed location and $1.12 \times 10^{6} \mathrm{~m}^{3}$ in the floodplain. Infiltration was therefore $23 \%$ greater than exfiltration. Infiltration only occurred for a short period (64\% of the infiltration occurred over four days) compared to exfiltration (64\% of the exfiltration occurred over 41 days), but with greater intensity. The high infiltration periods corresponded to flood events. In contrast, exfiltration occurred at lower rates than infiltration, but during the entire recession period. Water exchanges were very small outside flood periods (only 9\% of exchanges where the daily discharge was below $250 \mathrm{~m}^{3} \mathrm{~s}^{-1}$, representing $61 \%$ of the period length). Fig. 9 represents the spatial distribution of accumulated infiltration and exfiltration during the simulated period. Infiltration occurred over most of the floodplain area, with higher infiltration in terrain depressions. Exfiltration mostly occurred at the riverbank location, but was also localised in terrain depressions. Indeed, $88 \%$ of the infiltration and $40 \%$ of the exfiltration occurred in the floodplain area. Both exfiltration and infiltration occurred at the same time at different locations. It was also observed that in the first few days immediately after the flood, exfiltration rates were similar in the floodplain and riverbed areas, but after a few days exfiltration occurred primarily in the riverbed area.

In Table 2, exchanged volume is indicated for a below bankfull and an overbank flood event during the simulation period. The maximum discharge recorded for the overbank flood event was more than three times greater than the below bankfull flood event and was characterised by a 10 -year return period while the below bankfull event return period was one year. In terms of water exchanged, infiltration was 77 times greater and exfiltration 85 times greater during the overbank flood event than during the below bankfull flood event.

\subsection{Transport simulations}

The simulated average $\mathrm{Cl}^{-}$concentrations in the aquifer were performed with two different initial conditions corresponding to different $\mathrm{Cl}^{-}$concentrations in the agricultural area (scenarios IC80 and IC150). RMSE between observed and simulated values was $28.8 \mathrm{mg} \cdot \mathrm{L}^{-1}$ for both simulations, $\mathrm{R}^{2}$ and PBIAS were 0.34 and $35.9 \%$ respectively for IC80 and 0.46 and $-21.3 \%$ for IC150. Temporal series of simulated and measured $\mathrm{Cl}^{-}$concentrations for the piezometers equipped with a continuous water level sensor are shown in Fig. 10. Simulated concentrations were in good agreement with the observation for P9 for both scenarios. Simulated $\mathrm{Cl}^{-}$concentrations for P14 and P22 showed differences between the two simulations, with better results for the IC150 scenario than for the IC80 scenario. Finally, simulated $\mathrm{Cl}^{-}$concentrations for P7 and P18 had similar values for the IC80 and IC150 scenarios, but neither simulated concentration was able to represent the rise of $\mathrm{Cl}^{-}$concentrations observed in August and September. 


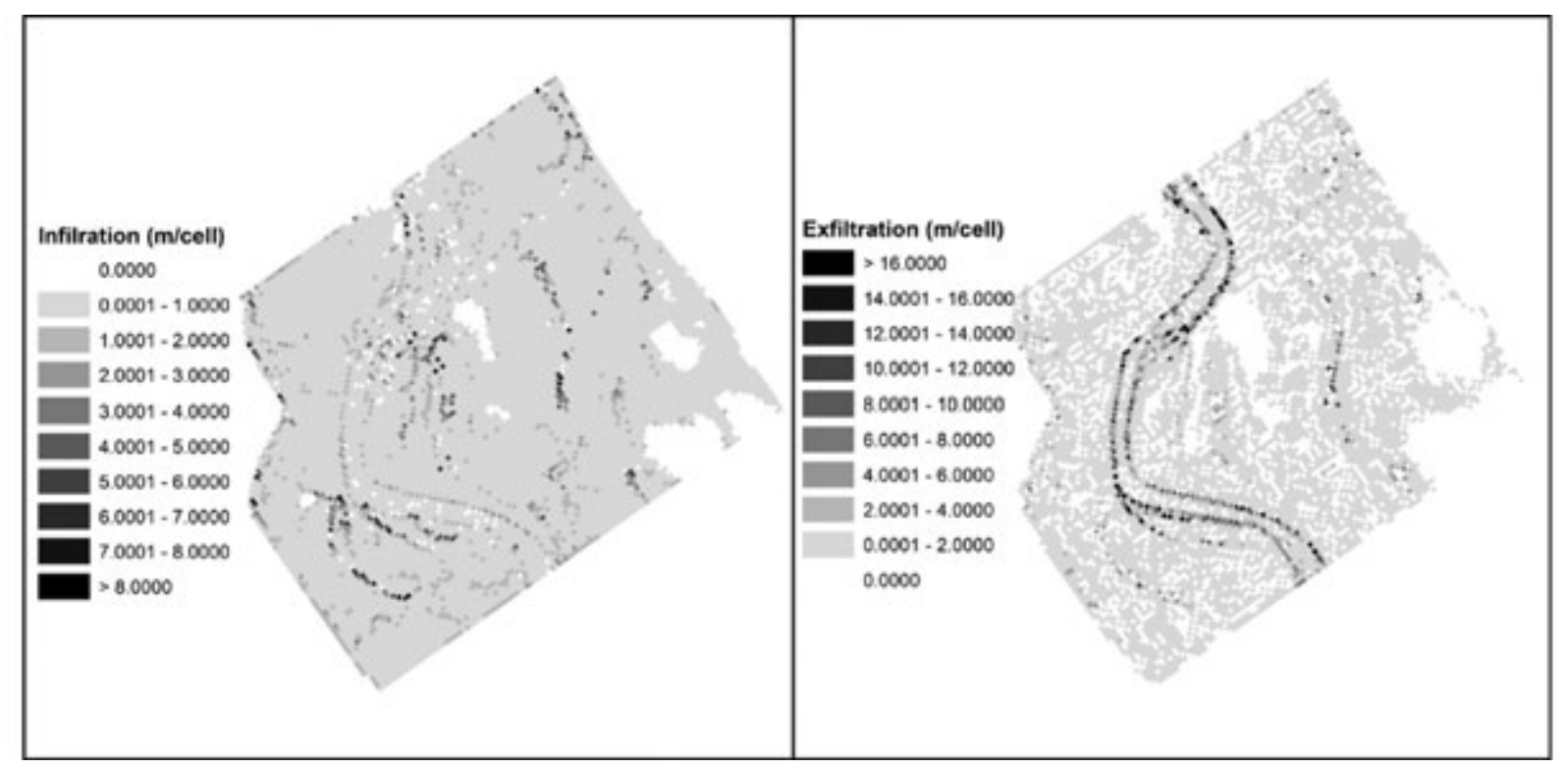

Fig. 9. Spatial pattern of accumulated infiltrated water (left) and exfiltrated water (right) during the simulated period.

Table 2

Instantaneous peak flow ( $\mathrm{Q}$ max) and estimated return period associated to a below bankfull and an overbank flood event. Volume of water infiltrated (Inf.), exfiltrated (Exf.) and net exchanges (Net) during the period indicated.

\begin{tabular}{llllll}
\hline Flood event & Period & $\mathrm{Q} \max \left[\mathrm{m}^{3} \cdot \mathrm{s}^{-1}\right]$ & Return period $[\mathrm{yr}]$ & $\operatorname{Inf}\left[10^{3} \mathrm{~m}^{3}\right]$ & ${\text { Exf }\left[10^{3} \mathrm{~m}^{3}\right]} \mathrm{Net}_{\left[10^{3} \mathrm{~m}^{3}\right]}$ \\
\hline Below bankfull & $23 / 05 / 2013-25 / 05 / 2013[3$ days $]$ & 790 & 1 & 30 & -10 \\
Overbank & $1 / 06 / 2013-10 / 06 / 2013[10$ days $]$ & 3010 & 10 & 2327 & -855 \\
\hline
\end{tabular}

Table 3

Volume of water infiltrated (Inf.), exfiltrated (Exf.) and net exchanges (Net) in $10^{6} \mathrm{~m}^{3}$ and the flood extent in km for the riverbed area ( $r$ ), the floodplain area (f) and the whole area (tot). Results are given for each return period flood (T).

\begin{tabular}{lllllllllll}
\hline & Inf. f & Inf. r & Inf. tot & Exf. f & Exf. r & Exf. tot & Net f & Net r & Net tot & Flood extent \\
\hline $\mathbf{T}=\mathbf{2} \mathbf{~ y r}$ & 0.81 & 0.15 & 0.96 & -0.14 & -0.28 & -0.42 & 0.67 & -0.13 & 0.54 & 3.2 \\
$\mathbf{T}=\mathbf{5} \mathbf{~} \mathbf{r}$ & 1.37 & 0.19 & 1.56 & -0.35 & -0.38 & -0.72 & 1.02 & -0.23 & 0.79 & 5.7 \\
$\mathbf{T}=\mathbf{1 0} \mathbf{~ y r}$ & 1.46 & 0.22 & 1.68 & -0.39 & -0.38 & -0.77 & 1.07 & -0.16 & 0.91 & 6.1 \\
$\mathbf{T}=\mathbf{2 0} \mathbf{~ y r}$ & 1.53 & 0.28 & 1.81 & -0.43 & -0.38 & -0.82 & 1.10 & -0.10 & 1.00 & 6.3 \\
\hline
\end{tabular}

\subsection{Application to different return period flood events}

Four different flood events corresponding to the two, five, 10 and 20-year return period maximum discharges were simulated. Exchanged volumes were calculated and separated into infiltration, exfiltration and net exchange for the riverbed, the floodplain and the whole area. The maximum flood extent, corresponding to the maximum area submerged during the simulations, was also computed (Table 3). The volume of SW-GW exchanges and flood extent area increased with the return period of the event. Only the exfiltration volume for the river area appeared to be limited to a threshold value for flood intensity above the five-year return period. The magnitude of the increase in water exchanges and flood extent area between the two and five-year return period was greater than the magnitude of the increase between the five and 20-year return period.

\section{Discussion}

The aim of the study was to assess SW-GW exchanges in a floodplain area using a model coupling a 3D flow in the porous media and 2D flow in the surface runoff including infiltration and exfiltration. The major feature included in this study was to capture overbank flow infiltration into the aquifer during large floods.
To assess the relevance of the model's application in areas with limited knowledge and available data, the parametrisation was performed a priori. The main parameters were defined using accessible information that could be obtained for a large number of sites. In addition to the requirement for a DTM of the studied area, the use of the model requires hydraulic conductivity that was set homogenously and correspondingly for a coarse alluvial aquifer and field measurement data. Soil retention parameters were derived from widely-used PTF based on soil texture. Manning coefficients were chosen from the literature (Chow, 1959) and reduced, as advised when considering 2D models (Néelz, 2009). Finally, dispersivity was chosen based on previous modelling studies (Peyrard et al., 2008). However the model was validated against an extensive observation dataset to assess the applicability of the model in similar contexts to that studied here.

Modelling the surface runoff with the 2D Saint-Venant equation using a finite volume method has been successfully applied to simulate flooding in floodplains (Horritt et al., 2007, Caleffi et al., 2003). In this study, simulated hydraulic heads for all the piezometers indicated the presence of overbank flow, although it was only observed in four of the five piezometers in which the water level was being monitored continuously, indicating that the simulated flood extent was being overestimated. This has already been observed in a study using the same equation but a different 
P9

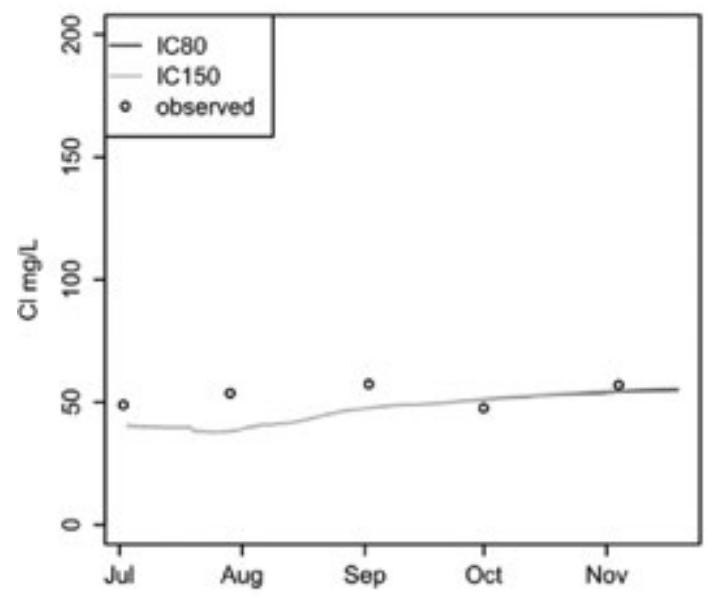

P14

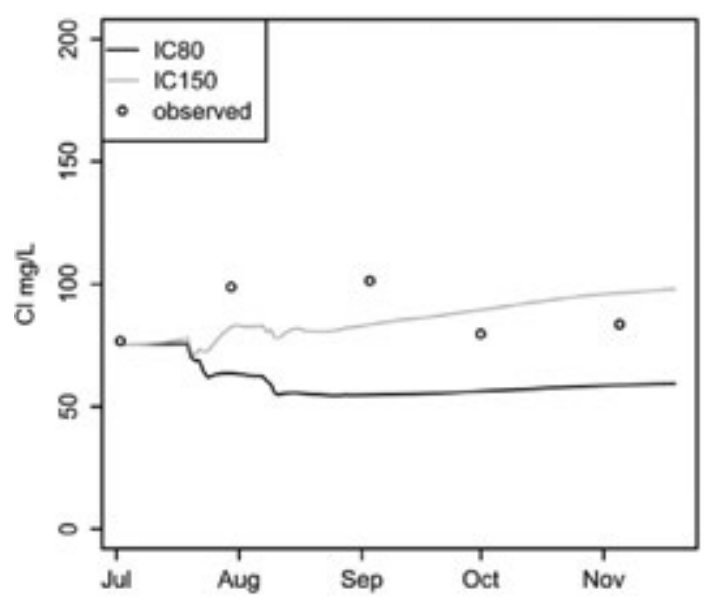

P22

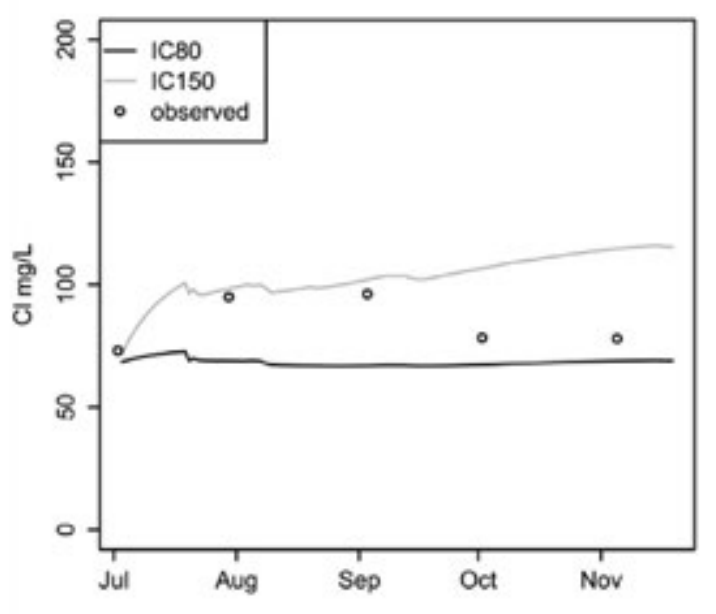

P18

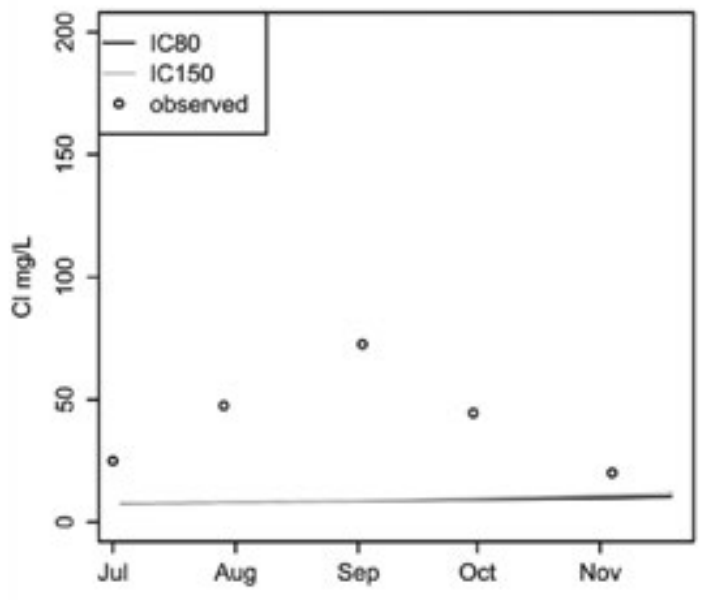

P7

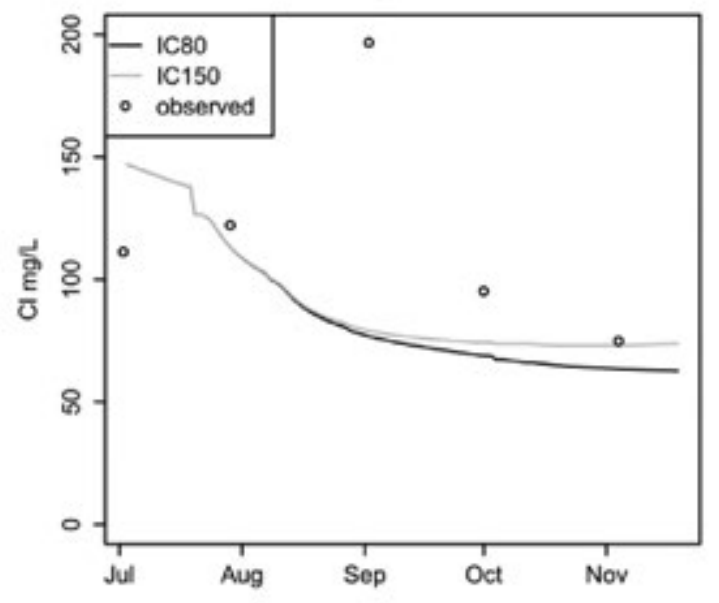

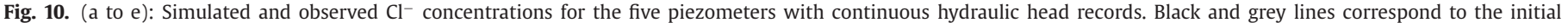
concentrations of $80 \mathrm{mg} \mathrm{L}^{-1}$ (scenario IC80) and $150 \mathrm{mg} \mathrm{L}^{-1}$ (scenario IC150) respectively in the agricultural area. 
numerical scheme method (Morales-Hernández et al., 2014), and is related to an incorrect definition in levees. Indeed, the grid resolution complicated the representation of small structures such as dykes and ditches that could prevent flow from reaching certain areas or could locally accelerate the dewatering rate. The 2D finite volume model also shows greater sensitivity to grid resolution than topographic sampling (Horritt et al., 2006). In addition, the flood extent is closely related to discharge input, and uncertainties in flood discharge evaluation can be a critical issue in this particular case (Di and Montanari, 2009). However a model using a finite volume method solving the 2D Saint-Venant equation has been shown to be less sensitive to the Manning parameter during high flow and especially the Manning coefficients for the floodplain (Horritt et al., 2007).

Despite the overestimation of the extent of the flood, the simulated hydraulic heads were in good agreement with the observed data. The rapid hydraulic head increase in the piezometers close to the river during the flood was well represented (P9, P14 and P18). Generally, the hydraulic heads simulated for the first peak flow of the simulated period matched reality, while the model results tended to be overestimated for the second peak flow. The good representation of hydraulic heads indicated that the simplification of hydraulic conductivity over the domain, which is known to be heterogeneous and important for SW-GW exchanges (Frei et al., 2009), did not appear to have a strong negative impact on the simulated hydraulic heads.

Modelling of conservative tracers $\left(\mathrm{Cl}^{-}\right)$was performed for two scenarios representing two levels of aquifer contamination by agriculture to validate the simulation of water fluxes. The results showed RMSE of $28.8 \mathrm{mg} \mathrm{L}^{-1}$ for both scenarios, but the results were found to be heterogeneous between piezometers. The simulation results showed that simulated $\mathrm{Cl}^{-}$concentrations for piezometers in locations under the influence of water-mixing between river and groundwater (P14) differed between the two scenarios. Other locations seemed to be mainly under the influence of the initial conditions defined in the agricultural area only (P22), since differences in initial conditions led to an increase in $\mathrm{Cl}^{-}$concentrations while no impact from dilution with river water was observed. Other locations were under the influence of the river alone (P9), since the simulated concentrations did not vary for different initial conditions, but dilution of $\mathrm{Cl}^{-}$concentrations could be observed. $\mathrm{Cl}^{-}$concentrations were well simulated for these piezometers when considering the scenario corresponding to the highest concentration in the agricultural area. This indicated that a good definition of initial concentrations in the agricultural zone was important for correctly simulating element concentrations in the monitored area. However, concentrations were not necessarily homogenous in the agricultural area and spatial and temporal variations could explain variations between observed and simulated concentrations. For other piezometers (P7 and P18), while simulated $\mathrm{Cl}^{-}$concentrations were close to observations for the first two months of simulations, the observations showed a rise in $\mathrm{Cl}^{-}$concentrations over the last three months which the model was unable to reproduce. Difficulties in representing $\mathrm{Cl}^{-}$concentrations for these piezometers could be explained by the presence of sources of $\mathrm{Cl}^{-}$that were not taken into account by the model. Indeed previous studies have shown that concentrations can rise when the water level reaches the higher soil layer (Ochoa-Salazar, 2008) and point source pollution might have occurred. For example in $\mathrm{P7}, \mathrm{Cl}^{-}$concentrations reached a level higher than initial conditions (around $200 \mathrm{mg} \mathrm{L}^{-1}$ ). In this case, the observed concentrations cannot be explained by the mix between river water and groundwater, therefore other processes have to be taken into account. This might explain the overall underestimation of $\mathrm{Cl}^{-}$ concentrations by the model (PBIAS of $-35.9 \%$ and $-21.1 \%$ for the IC80 and IC150 scenarios respectively). These results indicate that consideration of processes other than conservative transport is required to improve $\mathrm{Cl}^{-}$dynamic modelling. Nevertheless, the simulation could be considered satisfactory as the mixing processes near the river - where river water groundwater interactions are dominant - were well simulated, leading to a good representation of SW-GW exchanges in these area.

SW-GW exchanges were evaluated for the simulated period and exhibited strong spatial and temporal variations. Infiltration occurred mostly during the water-rising periods and in the days following the peak flow, and infiltration in the floodplain represented a large amount of the total water infiltrated. Exfiltration was occurring at a lesser intensity than infiltration, but throughout the entire recession period and mainly near the river location. Moreover, the two processes can occur in the same location but at different times. The importance of flow dynamics and short-term variation of river flow on SW-GW exchanges has already been pointed out in similar studies (Derx et al., 2010, Helton et al., 2014) and SWGW interactions are known to control the floodplain water balance (Helton et al., 2014). The results indicated that during the simulation period, infiltration was greater than exfiltration. This showed that extensive floods can influence groundwater storage over a number of months. Furthermore, these findings underlined the importance of taking infiltration from overland flow into account to represent exchanges during flood events accurately. Indeed in the case of large flood events similar to the one presented here, the volume infiltrated in the floodplain was greater than infiltration at the river location and accounted for $29 \%$ of the aquifer's maximum water volume. The importance of flooding on water exchanges and floodplain and water budget (Krause and Bronstert, 2007) is also confirmed by the results indicating that the exchanged water volume during a large overbank flood event (10-year return period) is more than 70 times greater than during an annual below bankfull flood event.

Modelling floods of different magnitudes according to the return period allowed conclusions to be drawn on the relationship between water exchange-related parameters and flood extent. The link between all water exchange parameters and water extent confirmed that accounting for overland flow during large floods is essential when assessing GW-SW exchanges. Exfiltration through the riverbank seemed limited to a certain threshold, meaning that the exfiltration volume would reach a limit in the areas close to the river while increasing in the floodplain for large floods. In addition major differences were found between the two-year return period flood and others of a higher magnitude. This showed that water exchanges in the floodplain can be very significant for the largest flood, and that exceptional events with a high return period flood might be of great importance in the mixing process in the floodplain compared to more common flood events with a lower intensity. However above a certain threshold (corresponding to the five-year return period in this study), the impacts of flooding on water exchanges were similar. Above this value, depending on the topography of the floodplain, the whole area of the floodplain is flooded and the porous media is fully saturated. This can have an impact on the residence time of surface water during floods that would decrease exponentially with river discharge due to a smaller percentage of surface water entering the subsurface (Helton et al., 2014).

The modelling approach in this study allowed an assessment of the importance of overbank flow for SW-GW exchanges during a flood event at reach scale. However, to represent these detailed SW-GW processes, the use of a distributed model of this kind required significant computation time and could only be applied at reach scale for a short time. In addition the results depended on the accuracy of the flood extent modelling, which requires a very detailed topography and considerable effort to incorporate topography features such as dykes and ditches in order to improve 
modelling results. Solute transport simulation was found to produce good results for some piezometers, while results for others were unsatisfactory. However this problem might be due to the use of a tracer (chloride) that not only reflects SW-GW mixing but can be influenced by other processes such as point source pollution and soil leaching that should be included in the model to improve simulation results. Furthermore, despite the good results with the actual parameterisation, a sensitivity analysis could be performed on key parameters such as hydraulic conductivity to provide a better assessment of the role of the parameters on model performance.

\section{Conclusions}

This study presented a modelling approach coupling physicallybased 2D surface runoff and unsaturated 3D flows in porous media to assess the water-exchange dynamics between surface water and groundwater in floodplains. Using a basic knowledge of the study site for parameterisation, the results revealed the model's ability to reproduce the local hydrology effectively. The model highlighted the spatial and temporal variability of infiltration and exfiltration patterns over the floodplain. SW-GW exchange periods were limited to flood events and the following few days. The results particularly underlined the importance of infiltration from overbank flow in SW-GW interactions during large floods. However, the impact of flooding on the floodplain water budget appeared to be similar for events above a certain threshold of flood intensity. Efforts have to be made to accurately model the flood extent, which is very sensitive to surface topography and important for correctly evaluating water exchanges since infiltrated volume is closely related to flood extent.

As overbank flood events and hyporheic fluxes are key elements in floodplain ecology and hydrology (Tockner et al., 1999, Krause et al., 2011), the modelling of SW-GW including this feature is fundamental for studying the flood plain environment. The modularity of the model structure allows further modules to be developed easily, including biogeochemical processes occurring in floodplain areas such as denitrification. Following this first step of hydraulic validation, the model could then be used to study the impact of management practices and different reach geomorphology on water exchange and associated biogeochemical cycles in floodplains.

\section{Acknowledgements}

This study was undertaken as part of the EU Interreg SUDOE IVB programme (ATTENAGUA - SOE3/P2/F558 project) and was funded by ERDF. This research was carried out as a part of "ADAPT'EAU" (ANR-11-CEPL-008), a project supported by the French National Research Agency (ANR) within the framework of the Global Environmental Changes and Societies (GEC\&S) programme. This work was granted access to the HPC resources of CALMIP under allocation P13119. The 1m-digital terrain model was provided by the French National Geographical Institute (IGN) and the discharge data by DREAL. The source code for the model used in this study, MOHID LAND, is free of charge and is available from mohid.codeplex.com. The authors thank Claire Tarring for helping to improve the English.

\section{References}

Amoros, C., Bornette, G., 2002. Connectivity and biocomplexity in waterbodies of riverine floodplains. Freshw. Biol. 47, 761-776. http://dx.doi.org/10.1046/j. 1365-2427.2002.00905.x

Baillieux, A., Campisi, D., Jammet, N., Bucher, S., Hunkeler, D., 2014. Regional water quality patterns in an alluvial aquifer: direct and indirect influences of rivers. J. Contam. Hydrol. 169, 123-131. http://dx.doi.org/10.1016/j.jconhyd.2014.09.002.

Bates, P.D., Stewart, M.D., Desitter, A., Anderson, M.G., Renaud, J.-P., Smith, J.A., 2000. Numerical simulation of floodplain hydrology. Water Resour. Res. 36, 25172529. http://dx.doi.org/10.1029/2000WR900102.
Bernard-Jannin, L., Sun, X., Teissier, S., Sauvage, S., Sanchez-Perez, J.M., 2016. Spatio-temporal analysis of factors controlling nitrate dynamics and potential denitrification hot spots and hot moments in groundwater of an alluvial floodplain. Ecol. Eng, in press.

Boano, F., Camporeale, C., Revelli, R., Ridolfi, L., 2006. Sinuosity-driven hyporheic exchange in meandering rivers. Geophys. Res. Lett. 33, 1-4.

Boano, F., Demaria, A., Revelli, R., Ridolfi, L., 2010. Biogeochemical zonation due to intrameander hyporheic flow. Water Resour. Res. 46, 1-13.

Bradford, R.B., Acreman, M.C., 2003. Applying MODFLOW to wet grassland in-field habitats: a casestudy from the Pevensey Levels, UK. Hydrol. Earth Syst. Sci. Discuss. 7, 43-55.

Braunschweig, F., Leitao, P.C., Fernandes, L., Pina, P., Neves, R.J.J. The object-oriented design of the integrated water modelling system MOHID. Develop. Water Sci. vol. 55, In: Science CTM and GFPBT-D in W, editor. Comput. Methods Water Resour. Vol. 2 Proc. XVth Int. Conf. Comput. Methods Water Resour., Elsevier; 2004, p. 1079-1090. doi:10.1016/S0167-5648(04)80126-6.

Brito, D., Campuzano, F.J., Sobrinho, J., Fernandes, R., Neves, R., 2015. Integrating operational watershed and coastal models for the Iberian Coast: watershed model implementation - a first approach. Estuar Coast Shelf Sci. 167, 138-146. http://dx.doi.org/10.1016/j.ecss.2015.10.022.

Brookfield, A.E., Sudicky, E.A., Park, Y.-J., Conant, B., 2009. Thermal transport modelling in a fully integrated surface/subsurface framework. Hydrol. Process. 23, 2150-2164. http://dx.doi.org/10.1002/hyp.7282.

Caleffi, V., Valiani, A., Zanni, A., 2003. Finite volume method for simulating extreme flood events in natural channels. J. Hydraul. Res. 41, 167-177. http://dx.doi.org/ $10.1080 / 00221680309499959$.

Chow, V.T., Maidment, D.R., Mays, L.W., 1988. Applied Hydrology. McGraw-Hill, New-York.

Chow, V.T., 1959. Open Channel Hydraulics. McGraw-Hill, New-York.

Condon, L.E., Maxwell, R.M., 2013. Implementation of a linear optimization water allocation algorithm into a fully integrated physical hydrology model. Adv. Water Resour. 60, 135-147. http://dx.doi.org/10.1016/j.advwatres.2013.07.012.

Correll, D.L., Jordan, T.E., Weller, D.E., 1992. Nutrient flux in a landscape: effects of coastal land use and terrestrial community mosaic on nutrient transport to coastal waters. Estuaries 15, 431-442.

Dagès, C., Paniconi, C., Sulis, M., 2012. Analysis of coupling errors in a physicallybased integrated surface water-groundwater model. Adv Water Resour. 49, 86 96. http://dx.doi.org/10.1016/j.advwatres.2012.07.019.

Derx, J., Blaschke, A.P., Blöschl, G., 2010. Three-dimensional flow patterns at the river-aquifer interface - a case study at the Danube. Adv. Water Resour. 33, 1375-1387. http://dx.doi.org/10.1016/j.advwatres.2010.04.013.

Di, B.G., Montanari, A., 2009. Uncertainty in river discharge observations: a quantitative analysis. Hydrol. Earth Syst. Sci. 13, 913-921.

Doppler, T., Hendricks Franssen, H.-J., Kaiser, H.-P., Kuhlman, U., Stauffer, F., 2007. Field evidence of a dynamic leakage coefficient for modelling river-aquifer interactions. J. Hydrol. 347, 177-187. http://dx.doi.org/10.1016/j.jhydrol.2007.09. 017.

Engeler, I., Hendricks Franssen, H.J., Müller, R., Stauffer, F., 2011. The importance of coupled modelling of variably saturated groundwater flow-heat transport for assessing river-aquifer interactions. J. Hydrol. 397, 295-305. http://dx.doi.org/10. 1016/j.jhydrol.2010.12.007.

Frei, S., Fleckenstein, J.H., Kollet, S.J., Maxwell, R.M., 2009. Patterns and dynamics of river-aquifer exchange with variably-saturated flow using a fully-coupled model. J. Hydrol. 375, 383-393. http://dx.doi.org/10.1016/j.jhydrol.2009.06.038.

Furman, A., 2008. Modeling coupled surface-subsurface flow processes: a review. Vadose Zo J. 7, 741-756. http://dx.doi.org/10.2136/vzj2007.0065.

Grimm, N.B., Fisher, S.G., 1984. Exchange between interstitial and surface water: implications for stream metabolism and nutrient cycling. Hydrobiologia 111 219-228.

Helton, A.M., Poole, G.C., Payn, R.A., Izurieta, C., Stanford, J.A., 2014. Relative influences of the river channel, floodplain surface, and alluvial aquifer on simulated hydrologic residence time in a montane river floodplain. Geomorphology 205 17-26. http://dx.doi.org/10.1016/j.geomorph.2012.01.004.

Hoffmann, C.C., Berg, P., Dahl, M., Larsen, S.E., Andersen, H.E., Andersen, B., 2006 Groundwater flow and transport of nutrients through a riparian meadow - Field data and modelling. J. Hydrol. 331, 315-335. http://dx.doi.org/10.1016/j.jhydrol. 2006.05.019.

Horritt, M.S., Bates, P.D., Mattinson, M.J., 2006. Effects of mesh resolution and topographic representation in 2D finite volume models of shallow water fluvial flow. J. Hydrol. 329, 306-314. http://dx.doi.org/10.1016/j.jhydrol.2006.02.016.

Horritt, M.S., Di Baldassarre, G., Bates, P.D., Brath, A., 2007. Comparing the performance of a 2-D finite element and a 2-D finite volume model of floodplain inundation using airborne SAR imagery. Hydrol. Process 21, 2745-2759. http://dx.doi.org/10.1002/hyp.6486.

Iribar, A., Sánchez-Pérez, J., Lyautey, E., Garabétian, F., 2008. Differentiated freeliving and sediment-attached bacterial community structure inside and outside denitrification hotspots in the river-groundwater interface. Hydrobiologia 598 109-121. http://dx.doi.org/10.1007/s10750-007-9143-9, LA - English.

Jégo, G., Sánchez-Pérez, J.M., Justes, E., 2012. Predicting soil water and mineral nitrogen contents with the STICS model for estimating nitrate leaching under agricultural fields. Agric. Water Manag. 107, 54-65. http://dx.doi.org/10.1016/j. agwat.2012.01.007.

Je, N., Sutcliffe, J.V., 1970. River flow forecasting through conceptual models part I-a discussion of principles. J. Hydrol. 10, 282-290.

Junk, W.J., Bayley, P.B., Sparks, R.E., 1989. The flood pulse concept in river-floodplain systems. Can. Spec. Publ. Fish Aquat. Sci. 106, 110-127. 
Kollet, S.J., Maxwell, R.M., 2006. Integrated surface-groundwater flow modeling: a free-surface overland flow boundary condition in a parallel groundwater flow model. Adv. Water Resour. 29, 945-958. http://dx.doi.org/10.1016/j.advwatres. 2005.08.006.

Krause, S., Bronstert, A., 2007. The impact of groundwater-surface water interactions on the water balance of a mesoscale lowland river catchment in northeastern Germany. Hydrol. Process. 21, 169-184. http://dx.doi.org/10.1002/hyp. 6182 .

Krause, S., Bronstert, A., Zehe, E., 2007. Groundwater-surface water interactions in a North German lowland floodplain - implications for the river discharge dynamics and riparian water balance. J. Hydrol. 347, 404-417. http://dx.doi.org/10. 1016/j.jhydrol.2007.09.028.

Krause, S., Hannah, D.M., Fleckenstein, J.H., Heppell, C.M., Kaeser, D., Pickup, R., Pinay, G., Robertson, A.L., Wood, P.J., 2011. Inter-disciplinary perspectives on processes in the hyporheic zone. Ecohydrology 4, 481-499. http://dx.doi.org/10. $1002 /$ eco.176.

Lancaster, R.R., 2005. Fluvial Evolution of the Garonne River, France: Integrating Field Data with Numerical Simulations Master's Thesis.

Maxwell, R.M., Putti, M., Meyerhoff, S., Delfs, J.-O., Ferguson, I.M., Ivanov, V., Kim, J., Kolditz, O., Kollet, S.J., Kumar, M., Lopez, S., Jie, N., Paniconi, C., Park, Y.-J., Phanikumar, M.S., Shen, C. Sudicky, EA, Sulis, M., 2014. Surface-subsurface model intercomparison: A first set of benchmark results to diagnose integrated hydrology and feedbacks. Water Resour. Res. 50, 1531-1549.

McClain, M.E., Boyer, E.W., Dent, C.L., Gergel, S.E., Grimm, N.B., Groffman, P.M., Hart, S.C., Harvey, J.W., Johnston, C.A., Mayorga, E., McDowell, W.H., Pinay, G., 2003. Biogeochemical hot spots and hot moments at the interface of terrestrial and aquatic ecosystems. Ecosystems 6, 301-312. http://dx.doi.org/10.1007/ s10021-003-0161-9.

Morales-Hernández, M., Hubbard, M.E., García-Navarro, P., 2014. A 2D extension of a Large Time Step explicit scheme (CFL $>1)$ for unsteady problems with wet/dry boundaries. J. Comput. Phys. 263, 303-327. http://dx.doi.org/10.1016/j.jcp.2014. 01.019 .

Morin, E., Grodek, T., Dahan, O., Benito, G., Kulls, C., Jacoby, Y., Van, L.G., Seely, M., Enzel, Y., 2009. Flood routing and alluvial aquifer recharge along the ephemeral arid Kuiseb River, Namibia. J. Hydrol. 368, 262-275. http://dx.doi.org/10.1016/j. jhydrol.2009.02.015.

Mualem, Y., 1976. A new model for predicting the hydraulic conductivity of unsaturated porous media. Water Resour. Res. 12, 513-522.

Néelz, S., 2009. Desktop Review of 2d Hydraulic Modelling Packages. Bristol: Environment Agency.

Nützmann, G., Levers, C., Lewandowski, J., 2013. Coupled groundwater flow and heat transport simulation for estimating transient aquifer-stream exchange at the lowland River Spree (Germany). Hydrol. Process. 28, 4078-4090. http://dx.doi. org/10.1002/hyp.9932.

Neves, R., 2013, The MOHID concept: Ocean Model Coast Management Studies with MOHID. In: Mateus, M., Neves, R. (Eds.). IST press, Lisbon, pp. 1-11.

Ochoa-Salazar, B.-X., 2008. Etude conjuguée géochimique/hydrologique des relations nappes-rivière dans une zone humide: cas de la zone humide alluviale de Monbéqui. Université de Toulouse III - Paul Sabatier, France.

Panday, S., Huyakorn, P.S., 2004. A fully coupled physically-based spatiallydistributed model for evaluating surface/subsurface flow. Adv. Water Resour. 27, 361-382. http://dx.doi.org/10.1016/j.advwatres.2004.02.016.

Partington, D., Brunner, P., Simmons, C.T., Therrien, R., Werner, A.D., Dandy, G.C., Maier, H.R., 2011. A hydraulic mixing-cell method to quantify the groundwater component of streamflow within spatially distributed fully integrated surface water-groundwater flow models. Environ. Model Softw. 26, 886-898. http://dx doi.org/10.1016/j.envsoft.2011.02.007.

Peyrard, D., Sauvage, S., Vervier, P., Sánchez-Pérez, J.-M., Quintard, M., 2008. A coupled vertically integrated model to describe lateral exchanges between surface and subsurface in large alluvial floodplains with a fully penetrating river. Hydrol. Process. 22, 4257-4273. http://dx.doi.org/10.1002/hyp.7035

Pinay, G., Ruffinoni, C., Wondzell, S., Gazelle, F., 1998. Change in groundwater nitrate concentration in a large river floodplain: denitrification, uptake, or mixing? J. North Am. Benthol. Soc. 17, 179-189. http://dx.doi.org/10.2307/1467961.

Purser, R.J., Leslie, L.M., 1988. A semi-implicit, semi-lagrangian finite-difference scheme using hligh-order spatial differencing on a nonstaggered grid. Mon. Weather Rev. 116, 2069-2080. http://dx.doi.org/10.1175/1520-0493(1988) 116〈2069:ASISLF〉2.0.CO;2.
Rassam, D.W., Pagendam, D.E., Hunter, H.M., 2008. Conceptualisation and application of models for groundwater-surface water interactions and nitrate attenuation potential in riparian zones. Environ. Model Softw. 23, 859-875. http://dx. doi.org/10.1016/j.envsoft.2007.11.003.

Richards, L.A., 1931. Capillary conduction of liquids through porous mediums. J. Appl. Phys. 1, 318-333.

Rivett, M.O., Buss, S.R., Morgan, P., Smith, J.W.N., Bemment, C.D., 2008. Nitrate attenuation in groundwater: a review of biogeochemical controlling processes. Water Res. 42, 4215-4232. http://dx.doi.org/10.1016/j.watres.2008.07.020.

Sánchez-Pérez, J.-M., Tremolières, M., 1997. Variation in nutrient levels of the groundwater in the upper rhine alluvial forests as a consequence of hydrological regime and soil texture. Glob. Ecol. Biogeogr. Lett. 211-217.

Sánchez-Pérez, J.-M., Vervier, P., Garabétian, F., Sauvage, S., Loubet, M., Rols, J.-L., Bariac, T., Weng, P., 2003. Nitrogen dynamics in the shallow groundwater of a riparian wetland zone of the Garonne, SW France: nitrate inputs, bacterial densities, organic matter supply and denitrification measurements. Hydrol. Earth Syst. Sci. Discuss. 7, 97-107.

Sánchez-Pérez, J.M., 1992. Fonctionnement hydrochimique d'un écosystème forestier inondable de la Plaine du Rhin: la forêt alluviale du secteur de l'île de Rhinau en Alsace(France). Université Louis Pasteur, Strasbourg.

Sauvage, S., 1999. Modélisation hydrobiogéochimique de la Garonne à l'étiage estival: cas de l'azote entre Toulouse et Agen (120 kilomètres). INPT, Toulouse.

Schaap, M.G., Leij, F.J., van Genuchten, M.T., 2001. ROSETTA: a computer program for estimating soil hydraulic parameters with hierarchical pedotransfer functions. J. Hydrol. 251, 163-176.

Sophocleous, M.A., 1998. Perspectives on sustainable development of water resources in Kansas. Kansas Geological Survey, Lawrence, Kansas, vol. 239 Bull 239.

Sophocleous, M., 2002. Interactions between groundwater and surface water: the state of the science. Hydrogeol. J. 10, 52-67. http://dx.doi.org/10.1007/ s10040-001-0170-8.

Sorooshian, S., Duan, Q., Gupta, V.K., 1993. Calibration of rainfall-runoff models: application of global optimization to the sacramento soil moisture accounting model. Water Resour. Res. 29, 1185-1194.

Steiger, J., James, M., Gazelle, F., 1998. Channelization and consequences on floodplain system functioning on the Garonne River, SW France. Regul. Rivers Res. Manag. 14, 13-23.

Stewart, M.D., Bates, P.D. Price, D.A. Burt, T.P., 1998. Modelling the spatial variability in floodplain soil contamination during flood events to improve chemical mass balance estimates. Hydrol. Process. 12, 1233-1255. http://dx.doi.org/ 10.1002/(SICI)1099-1085(19980630)12:8〈1233:AID-HYP614〉3.0.CO;2-2.

Swartzendruber, D., 1969. The flow of water in unsaturated soils. In: Flow through Porous Media. Academic Press, New York, pp. 215-292.

Thoms, M.C., 2003. Floodplain-river ecosystems: lateral connections and the implications of human interference. Geomorphology 56, 335-349. http://dx.doi.org/ 10.1016/S0169-555X(03)00160-0.

Tockner, K., Pennetzdorfer, D., Reiner, N., Schiemer, F., Ward, J.V., 1999. Hydrological connectivity, and the exchange of organic matter and nutrients in a dynamic river-floodplain system (Danube, Austria). Freshw. Biol. 41, 521-535. http://dx. doi.org/10.1046/j.1365-2427.1999.00399.x

Trancoso, A.R., Braunschweig, F., Chambel Leitão, P., Obermann, M., Neves, R., 2009. An advanced modelling tool for simulating complex river systems. Sci. Total Environ. 407, 3004-3016. http://dx.doi.org/10.1016/j.scitotenv.2009.01.015.

van Genuchten, M.T., 1980. A closed-form equation for predicting the hydraulic conductivity of unsaturated soils. Soil. Sci. Soc. Am. J. 44, 892-898.

Weng, P., Sánchez-Pérez, J.M., Sauvage, S., Vervier, P., Giraud, F., 2003. Assessment of the quantitative and qualitative buffer function of an alluvial wetland: hydrological modelling of a large floodplain (Garonne River, France). Hydrol. Process. 17, 2375-2392. http://dx.doi.org/10.1002/hyp.1248.

Woessner, W.W., 2000. Stream and fluvial plain ground water interactions: rescaling hydrogeologic thought. Ground Water 38, 423-429. http://dx.doi.org/10.1111/j. 1745-6584.2000.tb00228.x. 